\title{
Petrogenetic Study of the Multiphase Chibougamau Pluton: Archaean Magmas Associated with $\mathrm{Cu}-\mathrm{Au}$ Magmato-Hydrothermal Systems
}

\author{
Lucie Mathieu ${ }^{1, *(\mathbb{B} \text { and Denis Racicot }}{ }^{2}$ \\ 1 Centre d'études sur les Ressources minérales (CERM), Département des Sciences appliquées, \\ Université du Québec à Chicoutimi (UQAC), 555 boul. de l'université, Chicoutimi, G7H 2B1 QC, Canada; \\ lucie1.mathieu@uqac.ca \\ 2 Ministère de l'Énergie et des Ressources Naturelles (MERN), 5700 4e avenue, Québec, G1H 6R1 QC, Canada \\ * Correspondence: lucie1.mathieu@uqac.ca; Tel.: (+001)-418-545-5011 (ext. 2538)
}

Received: 13 February 2019; Accepted: 8 March 2019; Published: 12 March 2019

\begin{abstract}
The Chibougamau pluton is a Neoarchean multiphase intrusion that is related to $\mathrm{Cu}-\mathrm{Au}$ porphyry-style deposits. In Archean greenstone belts, porphyries are marginal and poorly documented mineralizations. Such deposits are, however, important in the Chibougamau area, where the main historical mining camp (Central Camp) is a magmato-hydrothermal system. Understanding such systems requires documenting the related magmatic rocks. This contribution focuses on the petrogenesis of the Chibougamau pluton to elucidate how the intrusion participated in $\mathrm{Cu}$ and $\mathrm{Au}$ mineralized systems. Using field descriptions, whole-rock analyses, and petrographic observations, we describe the source, emplacement mechanism, and chemical evolution of the Chibougamau pluton. The Chibougamau pluton is a TTD (tonalite-trondhjemite-diorite) suite that contains more $\mathrm{K}$ than most plutons of similar age. This suite was produced from a heterogeneous source; i.e., a hydrated basalt and possibly a metasomatized mantle. These are rare (and thus prospective) characteristics for an Archean intrusion. In addition, differentiation may have been sufficiently prolonged in the diorite phase to concentrate metals and fluids in the evolved magma. These magmatic constraints must now be tested against a renewed understanding of the $\mathrm{Cu}$-dominated mineralized systems of the Chibougamau area.
\end{abstract}

Keywords: Chibougamau pluton; $\mathrm{Cu}-\mathrm{Au}$ porphyry deposits; petrogenesis; TTD (tonalite-trondhjemitediorite) suite; magma

\section{Introduction}

Archean greenstone belts are assemblages of supracrustal rocks, typically mafic lava flows and clastic sedimentary rocks, and magma intrusions predominantly of tonalite-trondhjemite-granodiorite (TTG) affinity. In gold-endowed greenstone belts such as the Abitibi sub-province within the Superior craton, exploration and research tend to avoid large-volume granitoid suites, which are generally barren of VMS (volcanogenic massive sulfide) and orogenic gold deposits. However, these intrusions are prospective for magmato-hydrothermal systems; a type of deposit that is viewed as less abundant and economic, and that is less sought after than VMS and orogenic gold deposits [1]. Magmato-hydrothermal systems are, however, important in parts of the Abitibi sub-province, such as in the Chibougamau area where the historical mining camp (Central Camp) is described as a cluster of porphyry-style mineralizations [2-4]. However, many questions remain regarding the genesis of Archean magmato-hydrothermal systems [5]. The $\mathrm{Cu}-\mathrm{Au}$ Central Camp deposits, for example, are associated spatially with the multiphase Chibougamau pluton and are comprised of intermineral 
dykes, hydrothermal breccia, as well as other characteristics typical of porphyry deposits [6-13]. However, there are many differences between such Archean mineralizations and post-Archean porphyries, e.g., Archean ore bodies are dominated by $\mathrm{Au}$, sometimes $\mathrm{Cu}$, and tend to be less voluminous and less abundant than their modern counterparts [1,14]. Additionally, the source of magma for fluids and metals of these systems is poorly documented. The Chibougamau pluton, for example, is a multiphase intrusion comprised of tonalite and diorite that was emplaced at shallow depth; nonetheless, little is known of its chemistry and petrogenesis, leaving a number of unresolved questions. How many phases comprise the pluton? At what depth was the magma produced, and how did the magma evolve during its rise through the crust? Some of these questions have important implications for the metallogenic model, e.g., which intrusive phase is responsible for the mineralizing event? Other questions are important for exploration geologists, e.g., does magma associated with mineralization have remarkable (and prospective) chemistries?

This contribution addresses some of these issues by focusing on the Neoarchean Chibougamau pluton. This work relies on detailed mapping $[15,16]$, unpublished chemical analyses performed in the 1980s, and petrological observations. This data allows us to comment on the composition, evolution, and specificities of a pluton that is associated with several historically mined and currently explored $\mathrm{Cu}-\mathrm{Au}$ mineralizations.

\section{Geological Setting}

\subsection{Regional Geology}

The Chibougamau pluton, Québec, Canada, is located in the north-eastern corner of the gold-endowed Neoarchean Abitibi sub-province, which is the largest continuous greenstone belt of the Canadian Shield [17]. It extends between Ontario and Québec, and is located in the southern part of the Superior craton.

The evolution of greenstone belts can be summarized in two main stages. The synvolcanic period (1) is a construction phase characterized by intense magmatic activity that produces mafic lava plains, central volcanoes, as well as large-volume of tonalite-trondhjemite-granodiorite (TTG) suites and tholeiitic-layered complexes. The syntectonic period (2) that follows is characterized by deformation (mostly compression), sedimentary processes, and small-volume magmatic activity (e.g., monzonite, syenite). In the southern part of the Abitibi sub-province, the synvolcanic and syntectonic periods extend from >2750 to $2704 \mathrm{Ma}$ and from 2700 to $2670 \mathrm{Ma}$, respectively [18]. These events are diachronous and occurred earlier in the northern portion of the sub-province; for example, in the Chibougamau area, the periods extend from >2790 to $2710 \mathrm{Ma}$ (synvolcanic) and 2701 to $2690 \mathrm{Ma}$ (syntectonic) [19].

This contribution focuses on an intrusion of the synvolcanic period. In the Chibougamau area, this period consists of two main volcanic cycles that produced abundant mafic lava flows as well as intermediate to felsic extrusions and volcanoclastic deposits. The oldest volcanic products (2790-2760 Ma [20-22]) are of a limited extent. The volcanic cycle 1 consists of the undated, large-volume Obatogamau Formation (mostly basaltic to basalt-andesitic lava flows) and the 2729-2727 Ma [21,23] VMS-bearing Waconichi Formation (a complex assemblage of differentiated volcanic, volcanoclastic, and sedimentary products) (Figure 1). The volcanic cycle 2 comprises the 2724 Ma [22] Bruneau Formation (mafic to intermediate lava flows), the $<2721$ Ma [24] Blondeau Formation (assemblage of felsic extrusions, volcanoclastic and sedimentary products), and this cycle is topped by the Bordeleau Formation (sedimentary units) (Figure 1).

Several intrusions formed during the synvolcanic period, including TTGs and the ca. 2728 Ma [21] Lac Doré Complex (LDC), which is a layered complex dominated by anorthosite units and coeval with the cycle 1 of volcanism [25] (Figure 1). The syntectonic period, on the other hand, is dominated by sedimentary units (Opémisca Group), small to intermediate volume granodiorite intrusions (e.g., the ca. 2715 Ma Anvil pluton) [26], shoshonitic volcanism (the Haüy Formation of the Opémisca Group), and 
large-volume sanukitoid plutons (the Opémisca and Barlow plutons, 2700-2697 Ma) [21,27]. For a more detailed and recent review of the stratigraphy of the Chibougamau area, the interested reader is referred to the work of F. Leclerc [19].

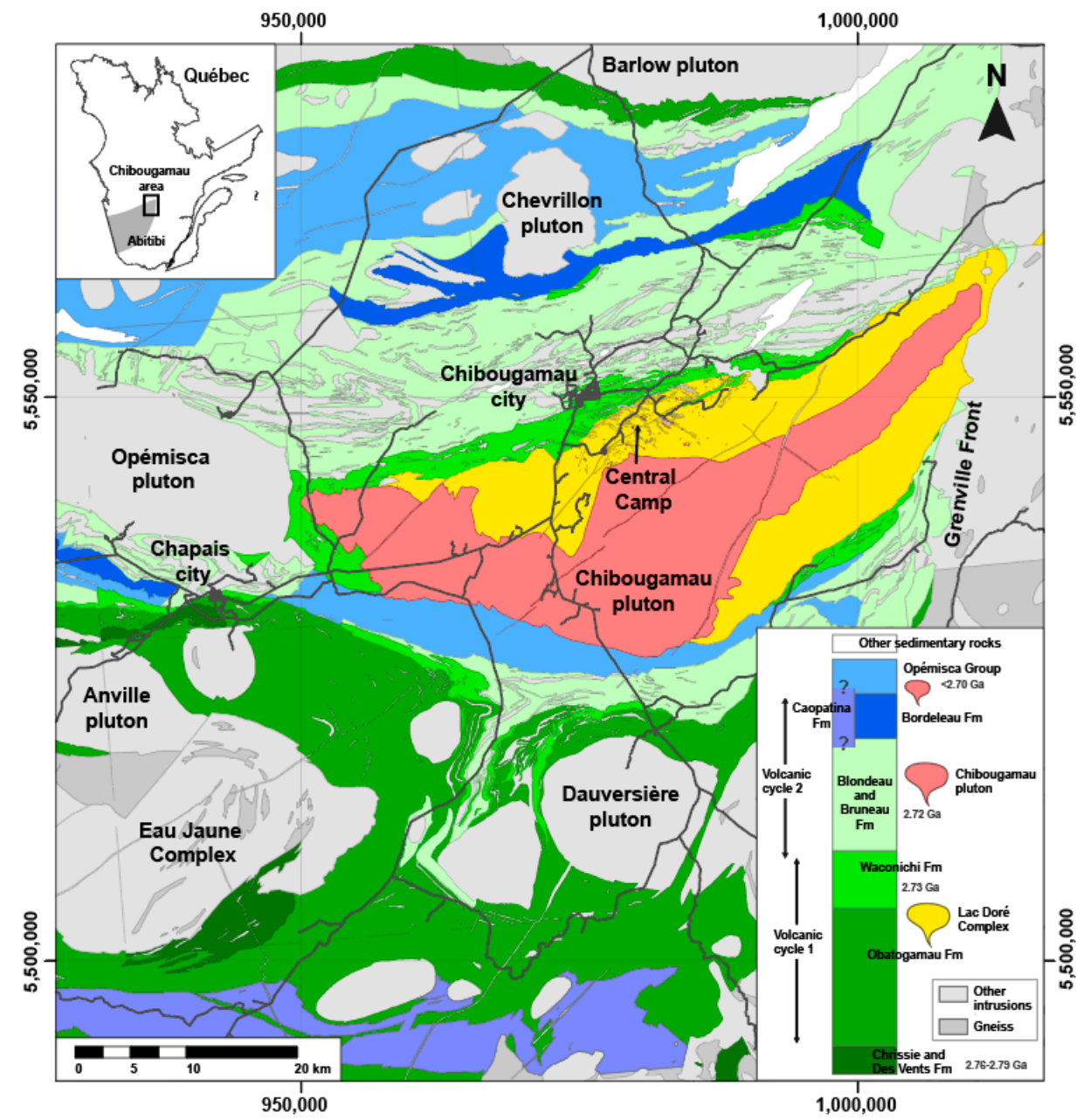

Figure 1. Geological map of the Chibougamau area, showing the main volcanic, sedimentary, and intrusive phases. The geological map is modified from the Ministère de l'Énergie et des Ressources Naturelles (MERN), Québec [28]. The projection is UTM NAD83 Zone 18N. This map presents the remaining units of the Gilman Formation in light green (i.e., color of the Bruneau and Blondeau Formations), following the most recent stratigraphic interpretation [19]. The Caopatina Formation is undated and its relationship with the volcanic cycle 2 and the Opémisca Formation is unresolved.

TTG magmatism is emblematic of the Archean, and it is particularly abundant during the synvolcanic period. Two main types of intrusions have long been recognized on the basis of field relationships: (1) the gneissic complexes (intrusions having a gneissic texture and a domal shape that have concordant contacts with their host rocks) that are emplaced at depth; and (2) the intrusions having massive and often porphyritic textures, with sharp and discordant contacts, that are emplaced relatively high in the crust [29]. Both types are observed in the Chibougamau area, and the Chibougamau pluton belongs to the shallowly emplaced category $[15,16]$.

The Chibougamau pluton is a 64-km-long and 1.6-3.2-km-wide intrusion having an aerial extent of $466 \mathrm{~km}^{2}$ (Figure 2). It is convex toward the south, possibly as a result of deformation along the nearby Grenville Front (Grenville Orogeny, ca. $1100 \mathrm{Ma}$ ) [30] (Figure 1). The Chibougamau pluton makes up the core of the Chibougamau anticline, a structure that may have developed as the pluton pushed its way toward the surface [31,32]. 


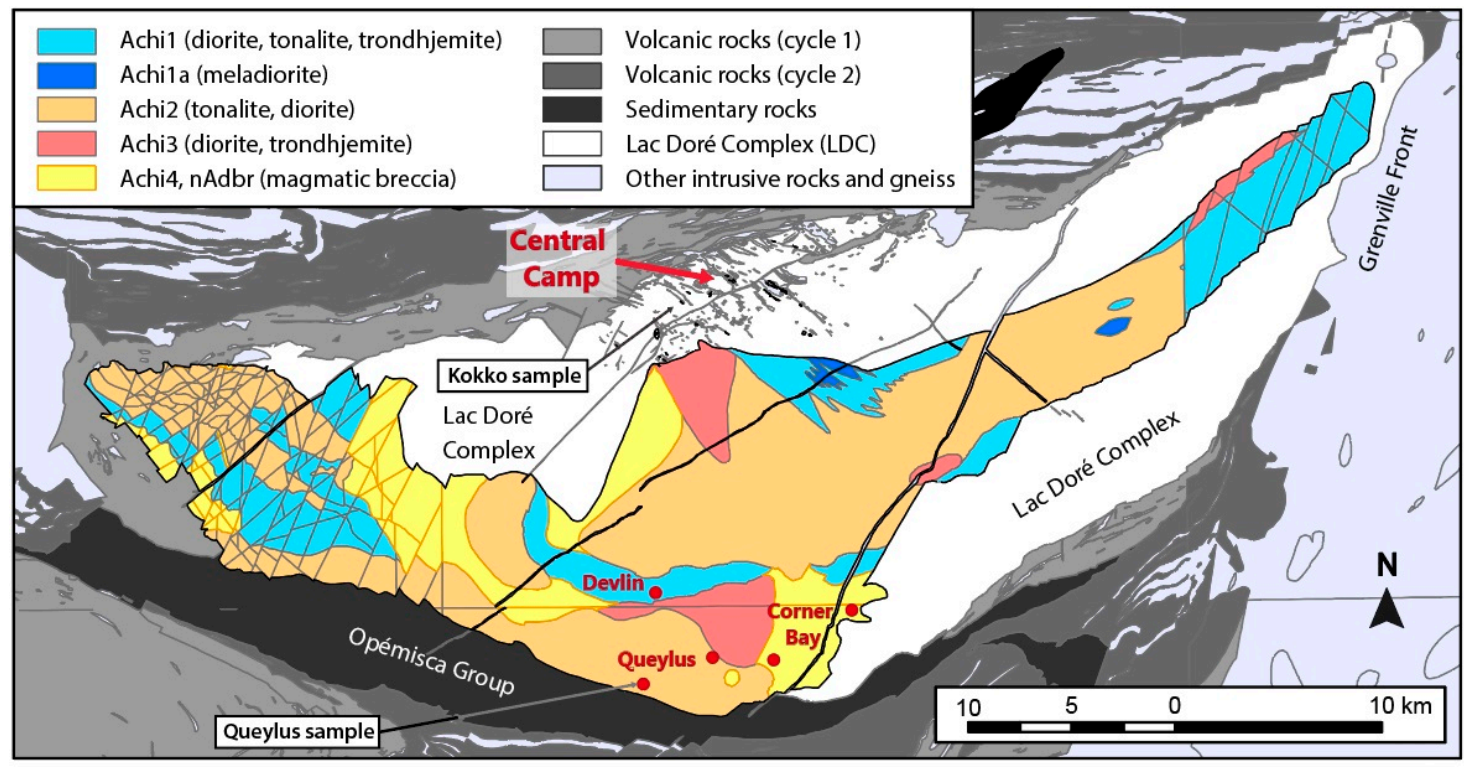

Figure 2. Geological map of the Chibougamau pluton [15,16] as compiled by the Ministère de l'Énergie et des Ressources Naturelles, Québec [28]. The projection is UTM NAD83 Zone 18N. The diorite- and tonalite-dominated areas are in blue and orange, respectively, and the magmatic breccia areas are in yellow.

The pluton was first identified in 1935, and it was fully mapped in 1977. This mapping was first summarized $[25,33]$ and then reviewed and completed in the early 1980 s by D. Racicot $[15,16]$. This latter work was motivated by the presence of intermineral dykes in the historical $\mathrm{Cu}-\mathrm{Au}$ mining camp (Central Camp). These dykes are related to an intrusive phase of the Chibougamau pluton [34].

Most of the Chibougamau pluton was emplaced between 2718 and $2715 \mathrm{Ma}$ [35,36] and this intrusive event is coeval with the cycle 2 of volcanism. Additional magma was then emplaced between 2705 and $2701 \mathrm{Ma}[20,37]$ during the syntectonic period. The pluton intruded rocks of the volcanic cycle 1, including the gabbro and anorthosite units of the LDC and, to the west, the volcanic rocks of the Waconichi Formation. The south-western portion of the pluton is in discordant contact with the conglomerates of the Opémisca Group (Figure 2), indicating that the pluton had already been exhumed when the Timiskaming-style basin was formed at $2700 \mathrm{Ma}[24,38]$, prior to the main deformation phase [39].

The Chibougamau pluton is a multiphase and asymmetric intrusion. It includes an abundance of tonalite and diorite dykes, pegmatites, feldspar-phyric units, as well as hydrothermal and magmatic breccia, all of which pointing to a shallow emplacement depth $[40,41]$. Based on field relationships, the emplacement depth is estimated to be a few kilometers; i.e., $<5 \mathrm{~km}$, possibly $2-4 \mathrm{~km}$ [42].

In greenstone belts, the chemistry of subvolcanic granitoid plutons is generally similar to that of contemporaneous volcanic products [1]. The Chibougamau pluton follows this general tendency, as it shares a calc-alkaline affinity with the volcanic rocks of the Blondeau Formation [41]; thus, there is a possible genetic link between this formation and the pluton [43-46]. The Chibougamau pluton is therefore considered as the volcanic chamber of the volcanic cycle 2 [47].

The Chibougamau pluton has been metamorphosed in the conditions of the greenschists facies, as have most rocks of the Abitibi sub-province $[48,49]$, but the magmatic textures are relatively well preserved. In the vicinity of the Grenville Front, however, the rocks have a gneissic texture and display amphibolite-grade metamorphism. To simplify the text, the prefix "meta-" is omitted from the rock names in this paper.

The structure of the Chibougamau area is dominated by large amplitude folds, and there is a lack of major breaks similar to those found in the gold-endowed structures observed in the southern part of the Abitibi sub-province. The elongated morphology of the pluton is comparable to the general $\mathrm{E}-\mathrm{W}$ 
structure of most of the Abitibi sub-province, which was affected by a main N-S compressional event known as the regional Kenorean Orogeny [50]. The pluton has been deformed by this event; however, its E-W morphology also likely reflects injections along an E-W synvolcanic structure [16]. Most of the foliation planes are parallel to the outline of the intrusion, and a portion of these structures may have a magmatic origin [16].

The pluton occupies the core of the Chibougamau anticline, and its exhumation began toward the end of the cycle 2 volcanism [47]. Its evolution can be summarized as follows: (1) emplacement of the pluton beneath a central volcano at ca. 2718-2716 Ma; (2) followed by exhumation at ca. 2714 $\mathrm{Ma}$; (3) emergence and erosion of the plutonic phases at ca. 2712-2710 Ma; and (4) deformation and additional magmatism during the main compressional event at ca. 2708-2695 Ma [12].

\section{2. $C u-A u$ Mineralization}

The Central Camp is the historical mining camp of the Chibougamau area. It is located north of the Chibougamau pluton, south of the homonym city, on the northern flank of the Chibougamau anticline. This "Chibougamau style" mineralization is contained mostly in the anorthosite rocks of the LDC (Figure 2). Most mining activities ended in the late 1990s, although the area is currently explored for $\mathrm{Cu}$ and $\mathrm{Au}$ (e.g., AmAuCu Mining Corporation, Toronto, ON, Canada).

Other $\mathrm{Cu}$ and $\mathrm{Au}$ projects and showings are located within rocks of the pluton, in the southern part of the intrusion (Figure 2). Cu-dominated showings are also observed north of the pluton, within the cycle 2 volcanic rocks and coeval intrusions. Further west, in the Chapais area (Figure 1), Cu mineralization is known as the "Opémisca style." The Central Camp mineralization thus appears to be part of one or several Cu-dominated mineralizing events whose timing, extent, origin, and significance are not fully resolved.

The mineralization in and around the Chibougamau pluton shows features (e.g., intermineral porphyritic dykes, hydrothermal breccia) that lead many authors to describe it as having a "porphyry style" [6-13]. The mineralization is mostly epizonal (i.e., formed at 1-2 km depth) [51], but shows local epithermal features (e.g., Lac Berrigan) [52-55]. Individual deposits have been extensively studied, and a comprehensive synthesis can be found in Pilote and collaborators [6,12].

Most studies have focused on the Central Camp deposits. These "Chibougamau style" mineralizations consist mostly of NW-SE-striking subvertical fractures filled with chalcopyrite, pyrrhotite, and pyrite. Other ore minerals include sphalerite, galena, and molybdenite, as well as free gold. The mineralization is structurally controlled by NW-SE fractures and E-W to ESE-WNW-striking faults with a normal to reverse movement [31,56] (Figure 2).

The main mineralization styles are (1) early sulfide-filled fractures and quartz veins and (2) late iron carbonate-magnetite-sulfide veins. A marginal style ("McKenzie-type") consists of gold-bearing quartz-carbonate-sulfide-tourmaline veins that may be related to a distinct and overprinting mineralizing event $[6,57]$. The main alteration assemblages consist of quartz, carbonate, white micas, chlorite, and K-feldspar [25,52]. The alteration may also include albitization [58].

Hydrothermal breccia developed only in parts of the camp deposits (e.g., Lac Clark deposit). Intermineral dykes are reported in most mines and showings [52,59-61]. In the Lac Clark deposit, an intermineral dyke yields an age of $2715.2 \pm 0.7 \mathrm{Ma}$ [6] and indicates that the mineralizing event occurred during the synvolcanic period. Studies of fluid inclusions reported two types of fluids: (1) a fluid having an elevated salinity $\left(\mathrm{CaCl}_{2}\right.$ and $\left.\mathrm{NaCl}\right)$ and (2) a methane-rich fluid [62].

The Central Camp mineralization is synvolcanic and corresponds to a magmato-hydrothermal system [7,12,56]. Remobilization of these deposits formed chalcopyrite veinlets, isolated gold nuggets [63], and it impacted on the structure of the mineralization [52,54]. A part of this remobilization occurred under relatively low-grade metamorphic conditions [64]. It may have occurred during the Proterozoic based on ages on galena [65,66], but syntectonic events are also possible [67].

Outside of the Central Camp, mineralization has developed within the intrusive phases of the Chibougamau pluton, e.g., the Queylus and Devlin breccias and the Corner Bay project (Figure 2). 
This mineralization is generally sub-economic and consists of stockworks, disseminated sulfides, extensive breccia, and overlapping hydrothermal alterations [6]. The timing of these mineralizing events is not fully resolved.

In summary, the $\mathrm{Cu}-\mathrm{Au}$ mineralization that is spatially associated with the Chibougamau pluton displays several characteristics of magmato-hydrothermal systems, including (1) hydrothermal alteration located in and around an intrusion [68], and (2) oxidized, high-salinity fluids and the related alteration minerals (e.g., K-feldspar and magnetite) [69,70]. The Chibougamau deposits also appear similar to the mineralized hairline fractures of the Cenozoic Koloula igneous complex, which corresponds to the deep and weakly mineralized portion of a porphyry system; i.e., the part that is not strongly influenced by meteoric water [71]. Dedicated studies are needed to refine the metallogenic model of the Central Camp; however, given the present level of understanding of these deposits, the "porphyry" designation is considered reasonable.

\section{Methodology}

\subsection{Field Data}

As with most of the economically relevant areas of the Abitibi sub-province, the deposits of Central Camp have been studied in detail. The associated plutonic rocks, on the other hand, have received little attention since the detailed investigation of their most recent mapping, summarized by two reports written in French $[15,16]$. The Chibougamau pluton was mapped in the 1980s as part of the geological mapping of Québec carried out by MRN (Ministère des Ressources Naturelles), now referred to as MERN (Ministère de l'Énergie et des Ressources Naturelles). This contribution uses a compilation of D. Racicot's data, as well as outcrop re-visited in 2018 (Figure 3), to reinterpret the petrogenic evolution of the Chibougamau pluton and to identify the magmatic factors favorable to the production of $\mathrm{Cu}-\mathrm{Au}$ magmato-hydrothermal mineralization.

The compiled field data include 2606 outcrops described in field notebooks, paper maps, and notes of D. Racicot. The compiled data correspond to the outcrop and sample numbers, as well as the main lithologies and their morphologies (main units, irregular injections, or dykes; Tables 1 and 2) observed in the field by D. Racicot. These outcrops were georeferenced using the ArcGIS software (Figure 4; Supplementary Material S1 and S2).

\subsection{Pyrite Chemistry}

The Chibougamau pluton is spatially, and likely genetically, related to $\mathrm{Cu}-\mathrm{Au}$ mineralization [6-13]. The nature of this relationship is commented using pyrite chemistry. Quantitative laser ablation inductively coupled plasma mass spectrometry (LA-ICP-MS) analyses were carried out on two polished thin sections at the LabMaTer (UQAC). These in situ analyses were performed in 2018 using a RESOlution ArF-193nm excimer laser ablation system (Australian Scientific Instrument, Fyshwick, Australia) equipped with a double-volume cell S-155 (Laurin Technics, Launceston, Australia), coupled to an Agilent 7900 ICP-MS (Agilent Technologies Santa Clara, CA, USA). The parameters used for these analyses were beam size of $75 \mu \mathrm{m}$, laser frequency of $20 \mathrm{~Hz}$ and an energy density of $3 \mathrm{~J} / \mathrm{cm}^{2}$. Pyrite and reference materials were analyzed using spots ( $20 \mathrm{~s}$ acquisition time), lines (10 $\mu \mathrm{m} / \mathrm{s}$ stage speed) and maps (beam size of $15 \mu \mathrm{m}$, scan speed of $10 \mu \mathrm{m} / \mathrm{s}$ ), after measuring the gas blank for $20 \mathrm{~s}$.

For most elements, calibration was performed using the UQAC-FeS-1 reference material, which is an artificial sulfide produced at UQAC [72] based on a modified technique developed by Garbe-Schönberg and Müller [73]. For $\mathrm{Ca}, \mathrm{Zr}$ and $\mathrm{Al}$, calibration was performed using the USGS reference material GSE-1g, which is a fused-basaltic glass containing c.a. $10 \%$ Fe and doped with $\sim 500$ ppm of each trace element [74]. MASS-1 (USGS) [75] was used as quality control reference material. Data quality was also monitored using the UQAC-FeS-5 reference material, as well as a massive sulfide reference material: CCU-1e, a copper concentrate (Canadian Certified Reference Materials Project-CCRMP). Pressed pellets were produced from CCRMP powdered reference material 
using a similar technique for the production of UQAC-FeS-1. It was presumed that the concentrations reported on the certificates of analysis provided by the CCRMP were not affected by the re-crushing procedure which involves 60 min of crushing in a Planetary Mills (Pulverisette 7, Fritsch, Idar-Oberstein, Germany) to reduce the powder to sub-microns particles sizes [73]. The results are in good agreement to working values (see Supplementary Material S3).

The data were reduced using the LADR 0.6.6.0 software (http:/ / norris.org.au/ladr) while IOLITE software (version 2.5) [76] was used to produce maps (Figure 5). The dwell time is $5 \mathrm{~ms}$ for each element. The internal standard ${ }^{57} \mathrm{Fe}$ and the stoichiometric value $46.55 \mathrm{wt} \%$ was used (source: [77]). The analyzed pyrites contain numerous silicate and sulfide inclusions that were included in the integrations. The inclusion-rich and -poor pyrites were exported using distinct integrations $(n=37)$. Representative analyses for pyrite are given in Table 3, and the full LA-ICP-MS dataset (including calibration) is provided in the electronic Supplementary Material S4.

Additional integrations were performed to compile "time-slice data sets" (TSD), following the recommendations of Gourcerol and collaborators [78]. In this contribution, the spot and line analyses were reduced using $2 \mathrm{~s}$ integrations. The advantage of this technic is that inclusions are treated as distinct analyses, while the 37 data described previously are mixed compositions (i.e., mean chemistry of pyrite, other sulfides and silicates). Once exported, data with $\mathrm{Si}>100,000 \mathrm{ppm}$ were removed from the dataset to discard the silicate analyzes. The remaining data ( $n=290$ and $n=205$ for the Kokko and Queylus samples, respectively) were processed using principal component analysis (PCA) (Figure 6).

PCA is a coordinate transformation method that can be used to reduce the dimensionality of a dataset ( $n$ observations and $m$ variables). The method calculates principal components (PC1, PC2, PC3 etc.) and by considering only PC1 and PC2, the dimensionality of the data is reduced from $m$ to two variables. In our case, $m=25$ variables, $n=290$ and $n=205$ (Kokko and Queylus sample) data (i.e., in situ pyrite analyzes integrated using $2 \mathrm{~s}$ intervals). A natural logarithm transformation is performed to facilitate the combination of the variables. The result of PCA is presented in a two-dimensional plot ("correlation circle"). In this plot, elements are distributed as a function of their degree of correlation (positive or negative) with respect to the components (PC1 and PC2 or PC3) that best explain the variability (Figure 6).

\subsection{Whole Rock Chemistry and Petrological Data}

The petrogenetic evolution of the pluton is interpreted using chemical and petrological data collected in the 1980s. These data were treated as part of a postgraduate study at École Polytechnique de Montréal. These petrological and chemical data have not, however, been fully made public. Some of these data can be found in the SIGEOM dataset of MERN. The compiled data includes: (1) 113 standard thin sections; (2) 135 microprobe analyses; (3) 121 whole-rock chemical analyses performed in the 1980s; and (4) eight whole-rock re-analyses performed in 2018.

Petrographic observations were performed on the 113 thin sections (Figures 7 and 8; Supplementary Material S5). The microprobe analyses were performed in the 1980s on amphibole and feldspar observed in polished thin sections. These polished thin sections have been lost, and the quality of these data could not be controlled. These analytical results are provided on an indicative basis (Figure 9).

The proportions of the main minerals observed in thin sections were evaluated in the 1980s based on point counting ( $n=2$ samples). Due to time constraints, this method could not be extended to the remaining 111 thin sections. In addition, most feldspars have been hydrated and are assemblages of albite, epidote, and white mica, which renders the modal estimate of the proportion of plagioclase and alkali feldspar difficult. For these reasons, a simplified normative calculation was used to estimate the proportions of the main phases, i.e., hornblende, biotite, anorthite, albite, orthoclase, and quartz. As discussed below, the sampled outcrops are weakly to moderately altered. For this reason, normative calculation approximates magmatic assemblages well.

The normative calculation was performed on the 121 rocks for which $\mathrm{FeO}$ and $\mathrm{Fe}_{2} \mathrm{O}_{3}$ had been analyzed (i.e., the 1980s dataset). A sequential calculation was performed by calculating normative 
apatite and titanite to exhaust $\mathrm{P}_{2} \mathrm{O}_{5}$ and $\mathrm{TiO}_{2}$. Then, normative biotite $\left(3 \mathrm{Si}, 1 \mathrm{Al}, 3 \mathrm{Mg}+\mathrm{Fe}^{2+}, 1 \mathrm{~K}\right)$ was calculated to exhaust $\mathrm{K}, \mathrm{Fe}$, or $\mathrm{Mg}$, depending on the samples, followed by the calculation of normative hornblende $\left(7 \mathrm{Si}, 1.75 \mathrm{Al}, 4 \mathrm{Mg}+\mathrm{Fe}^{2+}, 0.25 \mathrm{Fe}^{3+}, 1.8 \mathrm{Ca}, 0.2 \mathrm{Na}\right)$. Excess water was considered throughout this calculation. The remaining amount of $\mathrm{Na}, \mathrm{K}$, and $\mathrm{Ca}$ was then allocated to feldspar, and normative quartz was calculated using the remaining amount of Si. Ternary diagrams display the results of this calculation (Figure 10).

The 1980s samples were analyzed by $\mathrm{X}$-ray fluorescence for major, minor and trace elements $(\mathrm{Rb}$, $\mathrm{Sr}, \mathrm{Y}, \mathrm{Nb}, \mathrm{Zr}, \mathrm{Zn}, \mathrm{Cu}, \mathrm{Ni}, \mathrm{Cr}, \mathrm{Ba}, \mathrm{V})$ by MERN. The samples were also analyzed by titration and infrared, respectively, for iron $\left(\mathrm{Fe}_{2} \mathrm{O}_{3}\right.$ and $\left.\mathrm{FeO}\right)$ and volatiles $\left(\mathrm{CO}_{2}, \mathrm{H}_{2} \mathrm{O}^{+}, \mathrm{S}\right)$. Among these samples, 28 were analyzed for additional trace elements (rare earth elements - REE, Sc, $\mathrm{Cr}, \mathrm{Hf}, \mathrm{Ta}, \mathrm{Th}, \mathrm{U}, \mathrm{Sb}$ ) by neutronic activation at Université de Montréal (see Supplementary Material S6 and S7). These chemical data are displayed in several diagrams (Figures 11-15).

The 1980s chemical dataset provides invaluable insights into the major elements content of the Chibougamau pluton. The quality of the trace elements analyses is however debatable. In multi-element and REE diagrams, the irregular shape of the profiles is, in part, due to analytical imprecisions (Figure 14a,b). In addition, the apparent lack of a Nb anomaly in the 1980s analyses of diorite is likely due to analytical imprecisions for Th values (Figure 14a). For these reasons, eight samples were re-analyzed in 2018.

The eight whole-rock re-analyses were performed by ALS Chemex Labs Ltd (Vancouver, Canada). The major and minor elements were analyzed by ICP-AES, following acid digestion, and with detection limits of $0.01 \mathrm{wt} \%$. The trace elements were analyzed by ICP-MS, following a lithium borate fusion, with detection limits of 0.05 to $1 \mathrm{ppm}$. The metals were analyzed by ICP-AES, following a four-acid digestion, and detection limits were set at 0.5 to 2 ppm (see Supplementary Material S6).

\section{Results}

\subsection{Field Data}

The outcrops of the Chibougamau pluton generally consist of complex assemblages of dark (diorite) and light (tonalite) colored rocks of variable grain size and having diffuse to sharp contacts (Figure 3). The multiphase nature of the pluton can be appreciated at a meter-scale. The pluton is also heterogeneous at a tens-of-kilometer-scale (Figure 4) and consists of an assemblage of injections emplaced along an E-W axis.

Outcrops of the eastern portion of the pluton expose rocks having a gneissic texture. They consist of juxtaposed "ribbons" of mafic to felsic units (rubanement) of variable grain size; the magmatic textures have been obliterated by metamorphism and deformation during the Grenville orogeny. For this reason, the following description focuses on the central and western parts of the pluton where magmatic textures and structures are well preserved.

The main lithological units are diorite and tonalite (Table 1). These units have been subdivided based on color (meladiorite, quartz-diorite, biotite-tonalite, and leucotonalite; Table 2), grain size, and the nature of the main porphyritic phase (feldspar, biotite, amphibole, or chlorite) $[15,16]$. In this paper, the general designations of "diorite" and "tonalite" are favored (Table 2), even though some leucotonalite units may correspond to trondhjemite. In outcrops, these units can represent the dominant lithology, occur as enclaves within the main lithology, form injections having irregular shapes and sharp or diffuse contacts, or occur as linear dykes having sharp contacts. The intrusive contacts with irregular shapes correspond to magma mingling (Figure 3). Grain size in the outcrops may vary from a submillimeter- to centimeter-scale (Figure 3c). These grain-size variations are too irregular to correspond to compositional or textural layering; they may represent the result of multiple injections of phases carrying variable amounts of phenocrysts within conduits of variable thicknesses that cooled at different rates. 
The contact between the pluton and its host rocks (i.e., mostly anorthosite of the LDC) is irregular, and many enclaves of anorthosite and gabbro are observed in the tonalite and diorite units (Figure 4a). The magmatic breccia (Figure 2) consists of a 2-km-thick area of millimeter- to meter-long angular fragments of mostly LDC rocks, as well as aplite, diorite, and tonalite that are injected by fine-grained diorite and aplite [79]. The entire pluton is surrounded by diorite and tonalite injections (Figure 4a). Individual injections thus consist of plugs having massive cores surrounded by a large number of injections.

The compilation of cross-cutting relationships leads us to draw conclusions similar to those of D. Racicot $[15,16]$. The diorite phases (i.e., meladiorite and quartz-diorite with hornblende phenocrysts as well as quartz-bearing diorite) are observed as enclaves in tonalite (Figure $4 \mathrm{~b}$ ) and correspond to the earliest intrusive event. Massive diorite is preserved mostly in the western, eastern, and northern portions of the pluton and extends in the hosting material as injections having irregular shapes (Figure 4b). Subsequent injections of biotite-tonalite units form most of the exposed surface of the pluton. The main magma bodies lie in the central and eastern parts of the pluton and are rimmed by biotite-tonalite dykes (Figure 4c). The leucotonalite has a more limited extent. It is a late phase that occurs mostly as small-volume, irregular-shaped injections.
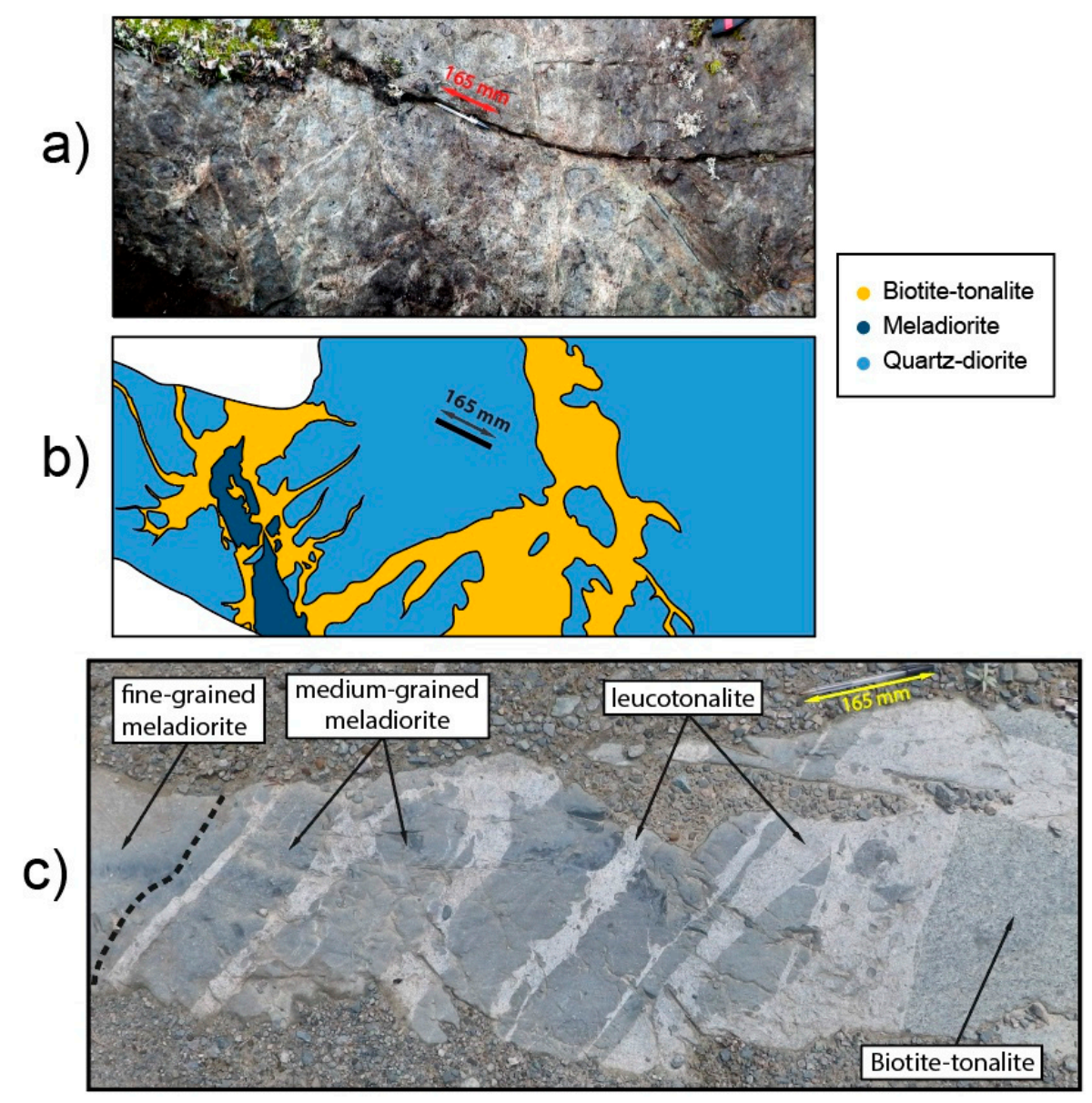

Figure 3. Example of outcrops of the Chibougamau pluton, displaying tonalite phases injected into diorite. For scale, the pen is 165-mm-long. The outcrops are situated at UTM coordinates (U18 NAD83) (a,b) 522654E and 5518642N; and (c) 522100E and 5518111N.

These cross-cutting relationships agree with the available geochronological data. The diorite phases are dated at 2718-2716 Ma (see Figure $4 \mathrm{~b}$ for details and references). Tonalite dykes that cut across the mineralization of the Central Camp have similar ages. Another quartz-feldspar-porphyry (QFP) tonalite dyke and a leucotonalite unit both yield an age of ca. 2705-2702 Ma (Figure 4c). 
The Chibougamau pluton consists of two main injection phases that occurred about 10 Ma apart. As the tonalite units of the first and second injection phases are undistinguishable in outcrops, the aerial extent of each injection phase is unconstrained.

The abundant dykes observed in and around the Chibougamau pluton have been classified into seven categories [61], a number then reduced to four by the MERN [19,80]. Most of these dykes have chemical affinities with phases of the Chibougamau pluton, but some dykes are gabbro (dolerite) that may correspond to feeders of the cycle 2 volcanic rocks and later magmatic events.

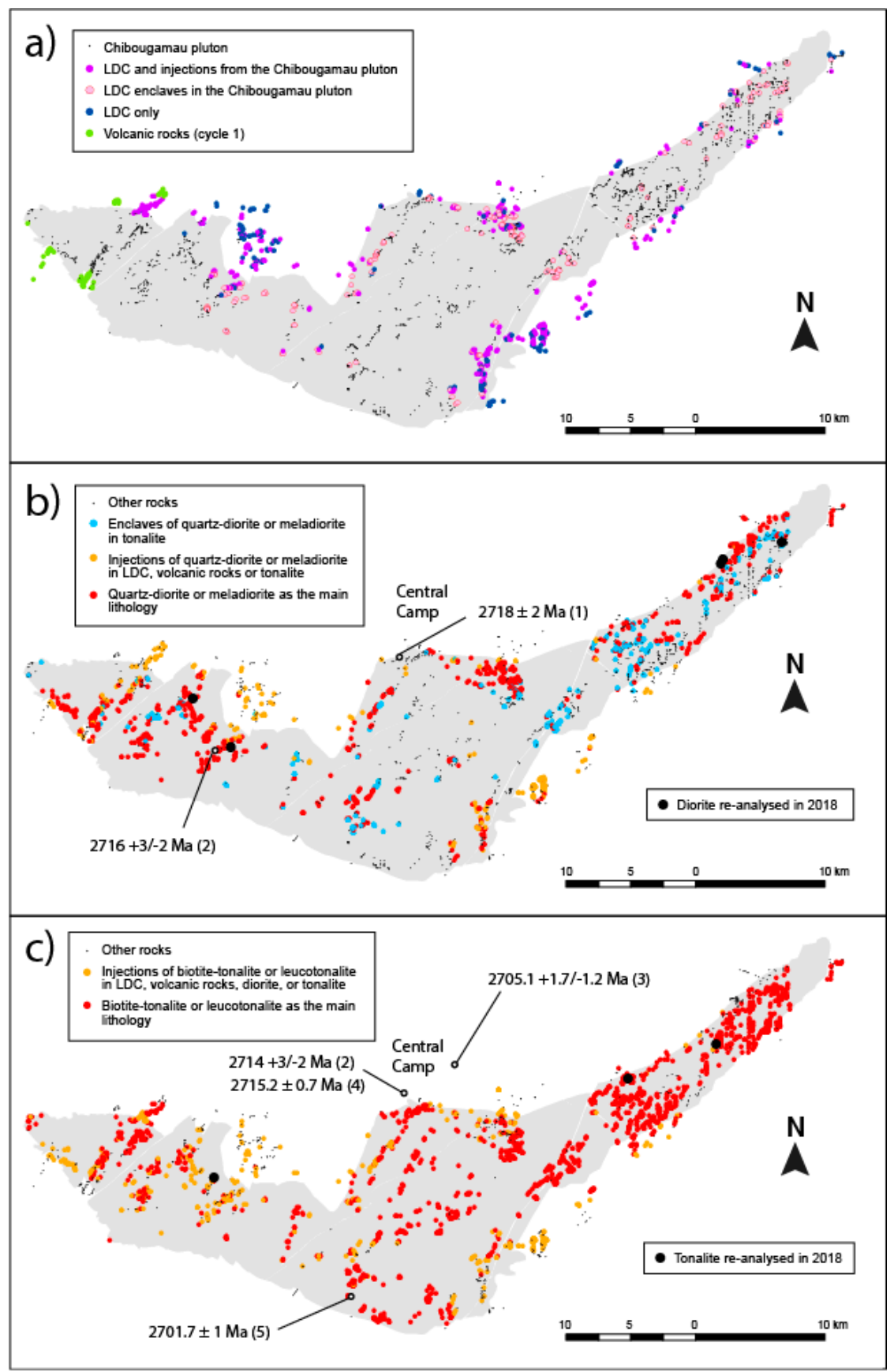

Figure 4. Outcrops described by D. Racicot in the 1980s and compiled using ArcGIS for the purposes of this study. Each outcrop displays one to three of the following units: (a) hosting material (anorthosite and gabbro from the Lac Doré Complex (LDC), volcanic rocks), (b) quartz-diorite and/or meladiorite, and (c) biotite-tonalite and/or leucotonalite. The geochronological data are from [6,20,34-36] for the ages numbered (1), (2), (3), (4) and (5), respectively. 
Table 1. Field and petrological characteristics of the main lithologies observed within Chibougamau pluton, from Racicot $[15,16]$.

\begin{tabular}{|c|c|c|}
\hline Lithology & Aerial Surface $(\%)$ and Contact & Petrology \\
\hline $\mathrm{Hbl}^{1}$-bearing meladiorite ${ }^{2}$ & $\begin{array}{l}7 \%{ }^{3} \text { - gradual contact with Qz-diorite, often seen } \\
\text { as enclaves in other phases }\end{array}$ & $\begin{array}{c}40 \%-90 \% \mathrm{Hbl} \text { and } \pm \mathrm{Bt}, 10 \%-50 \% \\
\text { interstitial and locally porphyric } \mathrm{Pl},<5 \% \\
\text { interstitial Qz, } \pm \mathrm{Ep}, \mathrm{Ap}, \mathrm{Spn}, \mathrm{Opq}\end{array}$ \\
\hline Hbl-bearing Qz-diorite & $13 \%$-gradual or sharp contacts with Bt-tonalite & $\begin{array}{l}20 \%-25 \% \mathrm{Hbl}(\text { up to } 50 \%), 5 \%-10 \% \mathrm{Bt} \\
10 \%-20 \% \mathrm{Qz}, 50 \% \mathrm{Pl}, \pm \mathrm{Ep}, \mathrm{Ap}, \mathrm{Spn}, \mathrm{Opq} . \\
\text { Typical facies: }>5 \% \text { Qz and }>25 \% \mathrm{Hbl}\end{array}$ \\
\hline Bt-bearing tonalite & $\begin{array}{l}75 \% \text { - a main unit of many outcrops, may also } \\
\text { occur as dykes. Coarse-grained porphyritic (Fsp } \\
\text { or Qz) and medium-grained varieties }\end{array}$ & $\begin{array}{c}10 \%-20 \% \mathrm{Bt} \text { (or } \mathrm{Chl} \text { ) and } \pm \mathrm{Hbl}, 60 \% \mathrm{Pl} \\
\text { (porphyric and groundmass, oscillatory } \\
\text { zoning), } 25 \% \text { Qz (elongated grains around } \\
\mathrm{Pl} \text { ), } \pm \mathrm{Ep}, \mathrm{Ap}, \mathrm{Spn}, \mathrm{Opq}\end{array}$ \\
\hline Leucotonalite & $5 \%$-Lenses and dykes that cut all the other units & $\begin{array}{c}<5 \% \mathrm{Bt},>25 \% \mathrm{Qz},<10 \% \mathrm{Mc}, 60 \% \mathrm{Pl}, \pm \mathrm{Ep}, \\
\mathrm{Ms}, \mathrm{Ap}, \mathrm{Spn}\end{array}$ \\
\hline
\end{tabular}

\footnotetext{
${ }^{1}$ Mineral abbreviations are as reported in the literature [81]; ${ }^{2}$ In the field, all the phases with $\mathrm{Hbl}$ as the main mafic phase (i.e., $\mathrm{Hbl}>\mathrm{Bt}$ ) are designated "quartz-diorite" or "meladiorite," depending on their Qz and Hbl proportions; 3 The aerial proportion of the main lithologies has been modified to add up to $100 \%$.
}

Table 2. Rock names used in this contribution.

\begin{tabular}{ccc}
\hline \multirow{2}{*}{ Lithology (Field Name) } & \multicolumn{2}{c}{ Designations Used in This Contribution } \\
\cline { 2 - 3 } & Lithology (Short Name) & Intrusive Phase \\
\hline $\begin{array}{c}\text { Hornblende-bearing meladiorite } \\
\text { Hornblende-bearing quartz-diorite } \\
\text { Biotite-bearing tonalite } \\
\text { Leucotonalite }\end{array}$ & $\begin{array}{c}\text { Meladiorite } \\
\text { Quartz-diorite } \\
\text { Biotite-tonalite } \\
\text { Leucotonalite }\end{array}$ & Diorite \\
\hline
\end{tabular}

\subsection{Relationship between Mineralization and Intrusive Rocks}

The $\mathrm{Cu}-\mathrm{Au}$ mineralization spatially associated with the Chibougamau pluton are porphyry deposits according to field relationships (e.g., hydrothermal breccia). The main evidences relating the hydrothermal system to the pluton are the 2715 Ma dykes $[6,36]$ that cut and are cut by the mineralization. Fluid chemistry provides additional evidences [62]. In this section, pyrite chemistry is used to further assess the nature of the mineralizing fluids.

Pyrite has been abundantly used to document mineralizing processes and fluid chemistry $[78,82,83]$. The pyrites considered in this section come from two distinct areas with alteration styles typical of the Central Camp (Kokko sample) and pluton-hosted (Queylus sample) hydrothermal systems (Figure 2). These outcrops were selected because they lack remobilization features (e.g., gold-enriched quartz-veins). The Kokko sample is located $600 \mathrm{~m}$ west of the old Kokko Creek open pit (Central Camp) and contains 10\% pyrite disseminated in sericitized anorthosite. The pyrites are euhedral minerals with: (1) porous cores enriched in sulfide and silicate inclusions; and (2) inclusion-poor rims (Figure 5). The Queylus sample comes from the main stripping of the Queylus project (Figure 2) and contains $30 \%$ pyrite disseminated in a sericitized and brecciated tonalite. In this sample, the pyrites are sub-euhedral minerals with sulfide and silicate inclusions-bearing core or rim area, depending on the grains.

The inclusion-bearing pyrites of the Kokko and Queylus samples are enriched in most trace elements (including $\mathrm{Cu}, \mathrm{Te}, \mathrm{Pb}$ and $\mathrm{Bi}$ ), while the inclusion-poor pyrites contain more $\mathrm{Ni}$ and $\mathrm{Se}$ (Table 3). The inclusion-bearing pyrites are enriched in $\mathrm{Cu}$ (chalcopyrite inclusions) and Au values are generally close to $0.01 \mathrm{ppm}$ (i.e., detection limit). These 37 analyses fail to reveal the chemical complexity of the studied pyrites. 
Table 3. Representative chemistry of pyrites from two samples.

\begin{tabular}{|c|c|c|c|c|c|c|c|c|c|}
\hline \multirow{2}{*}{\multicolumn{2}{|c|}{$\begin{array}{c}\text { Sample } \\
\text { Pyrite }\end{array}$}} & \multicolumn{4}{|c|}{$\begin{array}{c}\text { Kokko Sample } \\
(547,443,5,525,432){ }^{1}\end{array}$} & \multicolumn{4}{|c|}{$\begin{array}{c}\text { Queylus Sample } \\
(543,739,5,508,354)\end{array}$} \\
\hline & & \multicolumn{2}{|c|}{ Core $^{2}$} & \multicolumn{2}{|c|}{$\operatorname{Rim}^{2}$} & \multicolumn{2}{|c|}{ Inclusion-Rich } & \multicolumn{2}{|c|}{ Inclusion-Poor } \\
\hline \multicolumn{2}{|c|}{ Analyses } & \multicolumn{2}{|c|}{$n=10$} & \multicolumn{2}{|c|}{$n=13$} & \multicolumn{2}{|c|}{$n=5$} & \multicolumn{2}{|c|}{$n=9$} \\
\hline Element & Isotope & $\mathbf{M}^{3}$ & $\sigma^{3}$ & $\mathbf{M}$ & $\sigma$ & $\mathbf{M}$ & $\sigma$ & $\mathbf{M}$ & $\sigma$ \\
\hline $\mathrm{Al}$ (ppm) & 27 & 1788.8 & 3343.0 & 874.6 & 1955.8 & 391.88 & 548.73 & 2.52 & 10.00 \\
\hline $\mathrm{Si}$ & 28 & 2677 & 5082.2 & 2086 & 2812.7 & 823.65 & 3437.22 & 37.42 & 5.05 \\
\hline $\mathrm{Ca}$ & 44 & 978.41 & 2982.7 & 571.78 & 1826.6 & 41.22 & 75.58 & 5.62 & 2.74 \\
\hline $\mathrm{Ti}$ & 49 & 60.41 & 149.4 & 27.19 & 1985.4 & 53.72 & 163.53 & 10.44 & 1.92 \\
\hline $\mathrm{V}$ & 51 & 3.04 & 45.6 & 2.43 & 26.4 & 0.96 & 8.07 & 0.05 & 0.05 \\
\hline $\mathrm{Cr}$ & 53 & 0.26 & 0.86 & 0.21 & 0.62 & 0.62 & 0.21 & 0.08 & 0.06 \\
\hline $\mathrm{Mn}$ & 55 & 16.85 & 17.52 & 12.98 & 30.54 & 5.83 & 6.02 & 0.27 & 0.49 \\
\hline Co & 59 & 470.81 & 497.7 & 255.79 & 156.2 & 1666.2 & 1290.8 & 1582.2 & 6384.1 \\
\hline $\mathrm{Ni}$ & 61 & 117.83 & 80.4 & 122.93 & 32.5 & 41.61 & 550.50 & 282.56 & 867.88 \\
\hline $\mathrm{Cu}$ & 65 & 155.53 & 1727.1 & 8.65 & 93.0 & 3184.8 & 4476.6 & 30.85 & 54.15 \\
\hline $\mathrm{Zn}$ & 66 & 5.06 & 34.95 & 1.60 & 4.03 & 4.34 & 2.45 & 0.13 & 0.50 \\
\hline $\mathrm{Ga}$ & 71 & 0.27 & 1.22 & 0.31 & 0.34 & 0.43 & 1.95 & 0.01 & 0.01 \\
\hline $\mathrm{Ge}$ & 72 & 1.01 & 0.09 & 1.00 & 0.31 & 0.92 & 0.09 & 0.88 & 0.07 \\
\hline As & 75 & 4.66 & 12.94 & 1.89 & 16.04 & 31.31 & 307.33 & 7.88 & 10.79 \\
\hline Se & 82 & 5.11 & 1.64 & 5.46 & 2.94 & 17.64 & 13.90 & 26.4 & 30.16 \\
\hline $\mathrm{Ag}$ & 107 & 4.46 & 4.34 & 0.34 & 6.89 & 1.04 & 1.01 & 0.065 & 0.34 \\
\hline $\mathrm{Cd}$ & 111 & 0.06 & 0.48 & 0.01 & 0.01 & 0.02 & 0.07 & n.d. 4 & \\
\hline Sn & 118 & 0.18 & 0.56 & 0.04 & 1.42 & 1.97 & 1.40 & 0.11 & 0.36 \\
\hline $\mathrm{Sb}$ & 121 & 0.04 & 0.01 & 0.02 & 0.04 & 0.05 & 0.36 & 0.01 & 0.01 \\
\hline $\mathrm{Te}$ & 126 & 8.24 & 23.60 & 3.70 & 5.13 & 55.9 & 181.74 & 8.28 & 31.97 \\
\hline $\mathrm{Ba}$ & 138 & 0.45 & 0.94 & 0.46 & 1.40 & 3.92 & 12.45 & 0.12 & 0.09 \\
\hline $\mathrm{W}$ & 182 & 0.15 & 4.99 & 0.25 & 9.09 & 0.11 & 8.38 & 0.05 & 0.32 \\
\hline $\mathrm{Au}$ & 197 & 0.03 & 0.01 & 0.01 & 0.05 & 0.21 & 1.29 & 0.07 & 0.07 \\
\hline $\mathrm{Hg}$ & 202 & 0.36 & 0.05 & 0.34 & 0.09 & 0.41 & 0.18 & 0.22 & 0.15 \\
\hline $\mathrm{Tl}$ & 205 & 0.01 & 0.00 & 0.01 & 0.01 & 0.015 & 0.01 & n.d. & \\
\hline $\mathrm{Pb}$ & 208 & 10.34 & 148.75 & 2.55 & 39.08 & 1.59 & 13.75 & 0.24 & 0.78 \\
\hline $\mathrm{Bi}$ & 209 & 37.02 & 33.07 & 14.82 & 16.92 & 7.77 & 12.69 & 1.035 & 7.73 \\
\hline
\end{tabular}

${ }^{1}$ Location of samples (easting, northing). The projection is UTM NAD83 Zone $18 \mathrm{~N},{ }^{2}$ inclusion-rich core and inclusion-poor rim of pyrite, ${ }^{3}$ Statistics: median $(\mathrm{M})$ and standard deviation $(\sigma),{ }^{4}$ n.d. $=$ not detected.

The chemical map reveals that the porous core of the Kokko sample pyrite is enriched in silicates that control the distribution of most elements ( $\mathrm{Ba}, \mathrm{Al}, \mathrm{Sn}, \mathrm{Ca}, \mathrm{Cr}, \mathrm{Mn}, \mathrm{Si}, \mathrm{Ti}, \mathrm{V}, \mathrm{W})$. The porous core also contains $\mathrm{Ag}$ and $\mathrm{Cu}$ (chalcopyrite inclusions), $\mathrm{Bi}, \mathrm{Pb}$ and $\mathrm{Cd}$ (chalcopyrite and other inclusions) and $\mathrm{Te}$ (in pyrite). The inclusion-poor rim of the pyrite displays oscillatory zoning. The rim consists of an intermediate area with Co-rich and Co-poor zones and of an outer area that concentrates $\mathrm{Ni}, \mathrm{Te}, \mathrm{Se}$ and \pm As. These elements mimic the growth zoning and have a primary origin, which indicates that the Kokko pyrite has not been fully recrystallized by late processes such as metamorphism.

The chemical map shows that some elements concentrate in the core and in the outer rim of the pyrite (Te, $\mathrm{As}, \mathrm{Ni}, \pm \mathrm{Pb}$ ), while the metals exploited in the Chibougamau area (e.g., $\mathrm{Cu}$ ) concentrate in the porous core of the pyrite ( $\mathrm{Au}$ is undetected, and its distribution is presented below using spot and line analyses). The analyzed pyrite thus records an early mineralizing event (porous core) followed by additional pyrite growth within $\mathrm{Cu}$-barren hydrothermal fluids (overgrowth with oscillatory zoning).

The PCA performed on the spot and line analyses ( $2 \mathrm{~s}$ integrations) provides additional insights into elements associations (Figure 6). On both PCAs, most elements are controlled by the silicate (e.g., $\mathrm{Al}, \mathrm{Ca}$ and $\mathrm{Ba}$ in feldspar) and oxide (e.g., $\mathrm{Ti}, \mathrm{Cr}$ ) inclusions that are abundant in the core of the pyrite (Figure 5). Other elements are uncorrelated ( $\mathrm{Ni}, \mathrm{Co}, \mathrm{Se})$ because they mimic the growth zoning and concentrate in different zones (Figure 5). These elements substitute for $\mathrm{Fe}(\mathrm{Co}, \mathrm{Ni}$ ) and for $\mathrm{S}(\mathrm{Se})$ in pyrite [82]. The elements that are associated with $\mathrm{Cu}$ and $\mathrm{Au}$ are $\mathrm{Ag}, \mathrm{As}, \mathrm{Cd}$ and $\mathrm{Pb}$ (Kokko sample) and $\mathrm{Ag}$, $\mathrm{As}, \mathrm{Pb}, \mathrm{Bi}$ and possibly $\mathrm{Te}$ (Queylus sample). Additional elements association $(\mathrm{Hg}, \mathrm{Te}, \mathrm{Sb}$, $\mathrm{Bi}$ ) occur in the porous core of the pyrites of the Kokko sample. These elements likely concentrate in chalcopyrite $(\mathrm{Cu}, \mathrm{Ag})$ and in other inclusions such as galena or a Bi-Pb-bearing sulfosalt $(\mathrm{Bi}, \mathrm{Pb}, \mathrm{Sb}$, 
possibly Cd) [82]. Other elements occur as nonstochiometric substitutions in the lattice of pyrite (As, $\mathrm{Au}$ ) [82]. Tellurium usually occurs as stoichiometric substitutions for S (Figure 5). In the Kokko sample however, $\mathrm{Te}$ is associated with $\mathrm{Hg}, \mathrm{Sb}$ and $\mathrm{Bi}$ and these elements may occur in telluride inclusions (Figure 6).
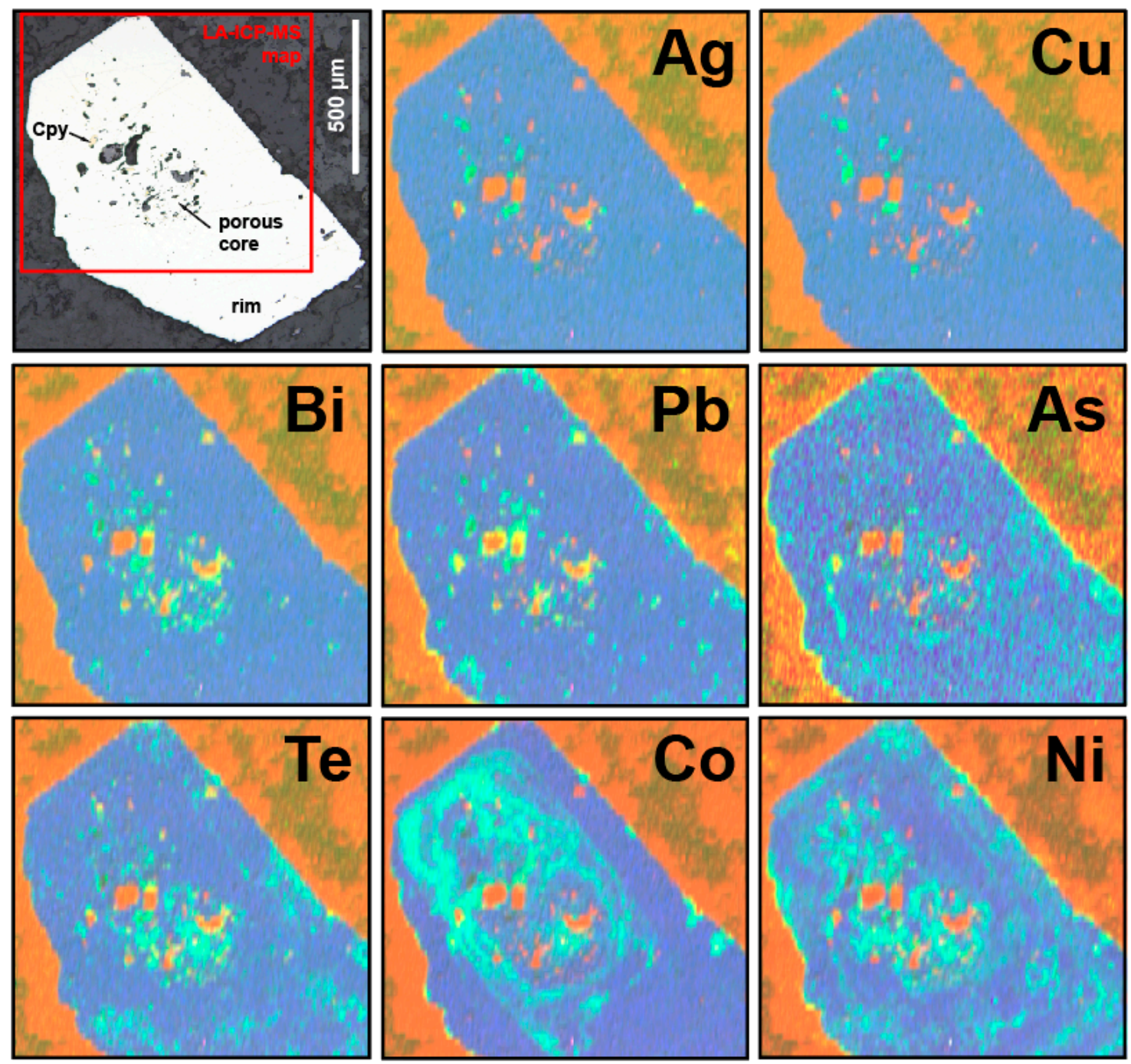

Figure 5. Reflected light image and chemical maps (LA-ICP-MS) of a pyrite of the Kokko sample. The analysed pyrite has a porous core enriched in silicate and chalcopyrite (Cpy) inclusions, and an inclusion-poor rim. The ${ }^{29} \mathrm{Si}$ (red) + element of interest (green) $+{ }^{33} \mathrm{~S}$ (blue) maps display three elements. The elements of interest are: ${ }^{107} \mathrm{Ag},{ }^{65} \mathrm{Cu},{ }^{209} \mathrm{Bi},{ }^{208} \mathrm{~Pb},{ }^{75} \mathrm{As},{ }^{126} \mathrm{Te},{ }^{59} \mathrm{Co}$ and ${ }^{60} \mathrm{Ni}$.

\subsection{Petrology}

Magmatic textures are recognizable in thin sections. However, metamorphic and hydrothermal alterations have destabilized feldspar (now albite, epidote, and white mica with a sericitic texture; Figure $7 \mathrm{~b}$ ) as well as amphibole and biotite (now actinolite and chlorite). Amphibole is generally well preserved, whereas fresh feldspar (Figure 7a) is only observed in 15 of 113 available thin sections.

Alteration minerals (white mica, carbonate, pyrite) are restricted to the known mineralized area. Altered biotite is found locally at the expense of amphibole (Figure 7c). Hornblende pseudomorphed by biotite is a common expression of K-metasomatism in porphyry mineralization [84,85]. 

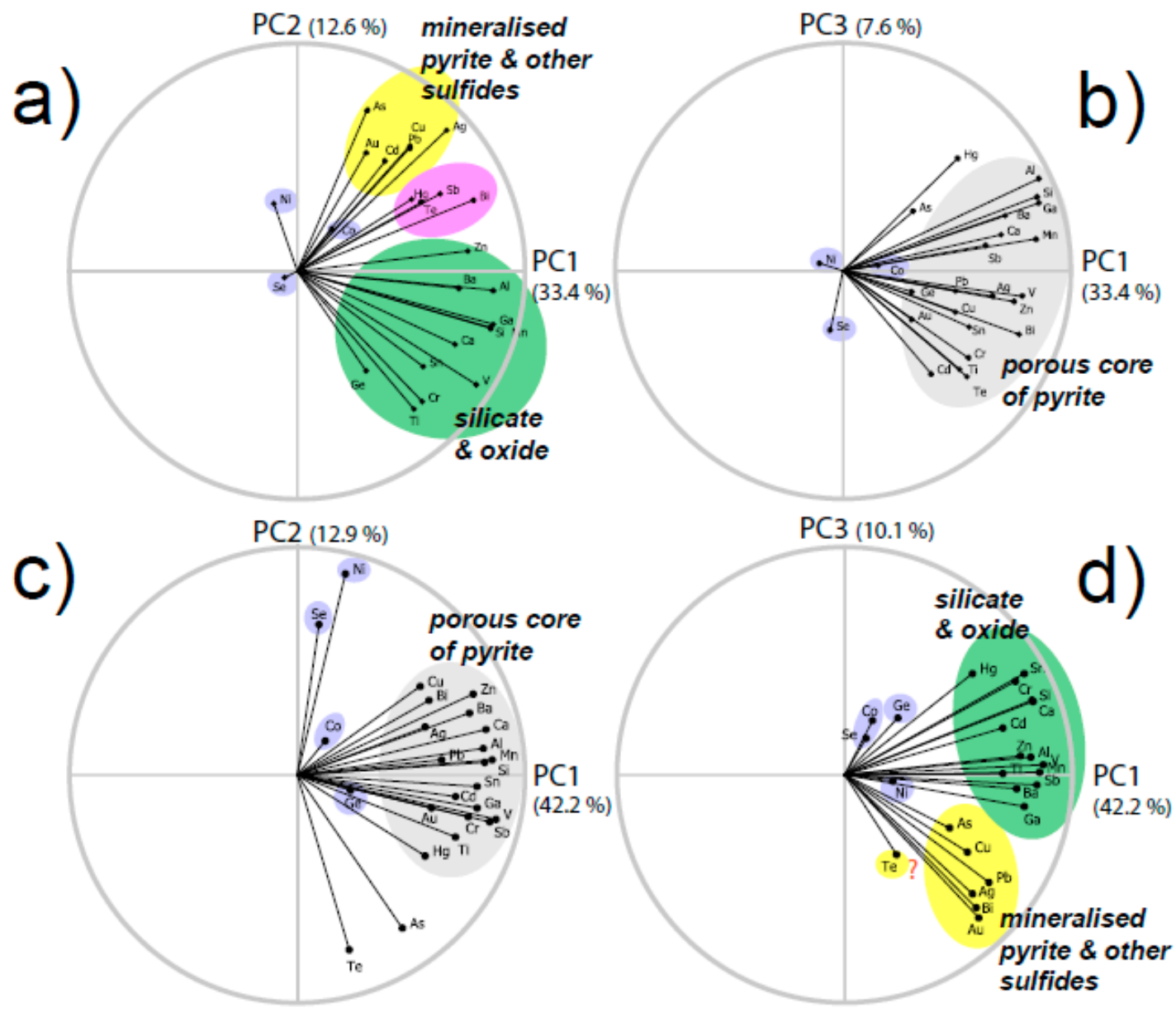

Figure 6. Principal component analysis (PCA) diagrams for pyrite grains from in-situ lines and spot analyses performed on the Kokko $(\mathbf{a}, \mathbf{b})$ and Queylus (c,d) samples as a function of PC1 and PC2 $(a, c)$ and PC1 and PC3 (b,d). The field colors correspond to element associations defined from microscopic observations and element maps. These fields correspond to: (1) porous core of pyrite (grey field); (2) inclusion-poor rim with oscillatory zoning (purple field); (3) silicate inclusions (green field); and (4) elements associated with $\mathrm{Cu}$ and $\mathrm{Au}$ (yellow field). An additional field (pink) is observed in the Kokko sample (a) and includes elements associated with $\mathrm{Te}$ and $\mathrm{Bi}$ in the porous core of pyrite.

In the Chibougamau pluton, however, most of the observed mica are recrystallized magmatic biotite. Biotite re-equilibrates much faster than amphibole [71], which is probably why destabilized amphiboles are rare in the pluton. However, amphiboles are partially recrystallized and have irregular outlines (Figure 8a,c,e). Deuteric actinolite replaces pyroxene in the gabbroic units of the LDC and some magmatic hornblende in the most hydrated units of the pluton. Most of the analyzed amphiboles are magnesiohornblende (Figure 9a) and there is no evidence that these amphiboles correspond to a destabilized pyroxene.

Grain size is variable in most rocks. The largest grain-size differences between the phenocrysts and groundmass are observed in dykes (Figure 8e,f), but phenocrysts are distinguishable in most parts of the pluton (Figure $8 \mathrm{a}, \mathrm{c}, \mathrm{e}$ ). Amphibole and biotite are both phenocrysts and groundmass minerals. The main phenocrystic phase is, however, a zoned and euhedral plagioclase (Figure 8b,d). 

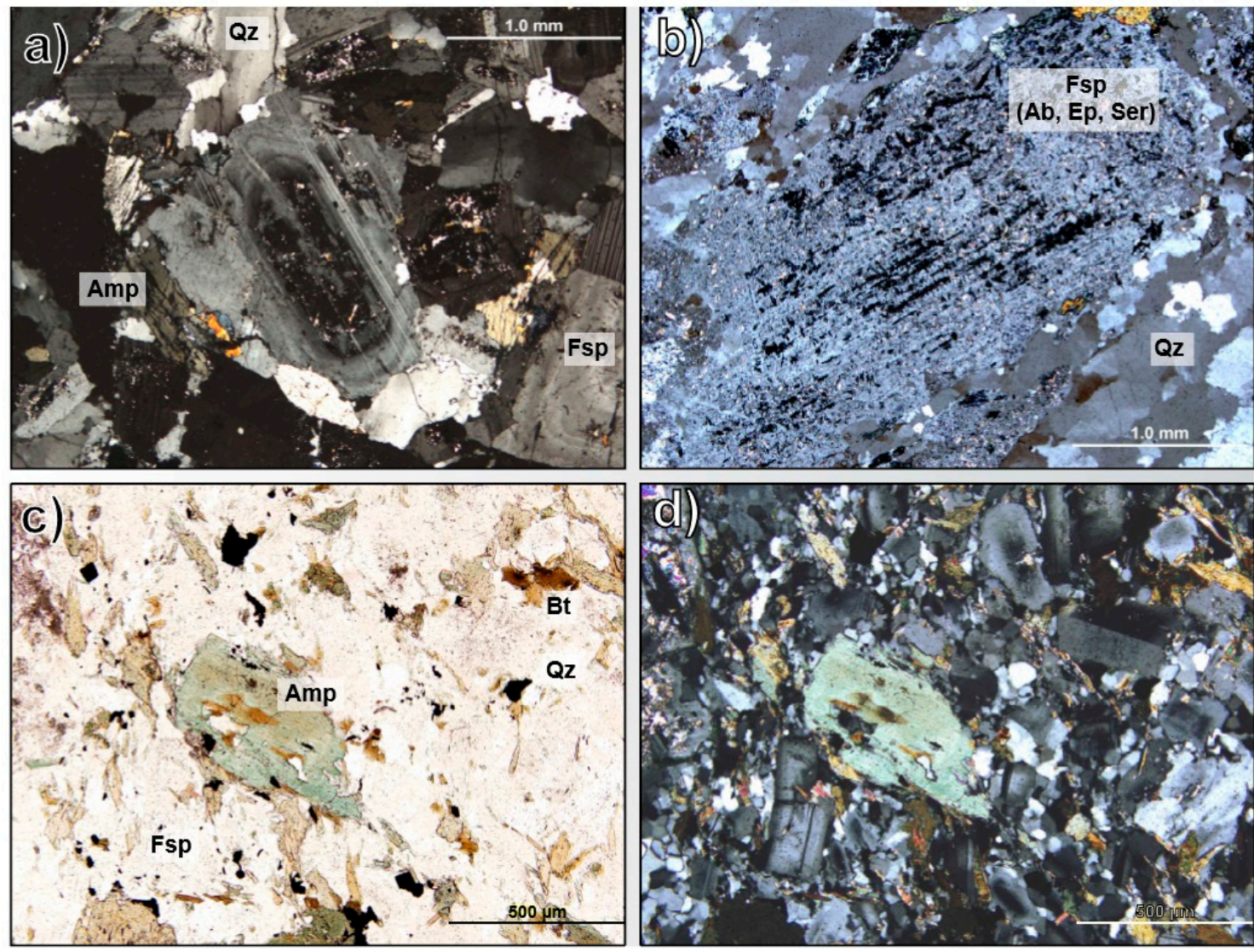

Figure 7. Cross polarized $(\mathbf{a}, \mathbf{b}, \mathbf{d})$ and plane transmitted (c) light microphotographs, displaying typical examples of fresh feldspar with oscillatory zoning ((a) (quartz-diorite, sample PLD-30-5A) and strongly altered feldspar ((b) (biotite-tonalite, sample PMD-20-2). Sample 5A-32R-2C (c,d) is a quartz-diorite with porphyritic feldspar and hornblende, a quartz- and feldspar-dominated groundmass and hornblende partially replaced by biotite. Mineral abbreviations are as reported in the literature [81].

The feldspar is mostly labradorite to andesine in the diorite units and andesine to oligoclase in the tonalite units (Figure 9b). Albite may correspond to a metamorphic mineral, given the abundance of epidote observed in thin sections. Some anorthoclase is reported in diorite and alkali feldspar (microcline), which are coarse to fine-grained, are restricted to the tonalite units (Figure 9b). Feldspar also occurs in groundmass. Quartz is abundant and is generally restricted to the groundmass, except in some QFP dykes. The main accessory phases are apatite and titanite.

The rocks of the Chibougamau pluton are dominated by feldspar, as well as ferromagnesian minerals and quartz for diorite and tonalite, respectively (Figure 10b,d). Some scatter is observed on the feldspar diagrams (Figure 10a,c), likely due to alteration such as sericitization. Nonetheless, the tonalite are sodic rocks that define a trondhjemite trend (Figure 10a,c). Tonalite are feldspar-dominated rocks $(50 \%-70 \%)$ with $20 \%-40 \%$ quartz and $<10 \%$ biotite and, rarely, amphibole (Figure $10 \mathrm{~b}, \mathrm{~d}$ ). Diorite display more variable compositions: the quartz-poor variety is a mixture of feldspar and amphibole \pm biotite (ca. 55:45), while the quartz-rich variety contains less mafic minerals (ca. 20:50:30 for quartz, feldspar, and amphibole \pm biotite). The studied rocks contain equivalent amounts of feldspar (ca. $50 \%-60 \%$ ). Diorites are dominated by plagioclase (ca. 35:65 for normative anorthite and albite) (Figure 10a). Tonalite contains orthoclase, as well as an equivalent amount of albite and less anorthite than the diorite (ca. 20:70:10 for normative anorthite, albite, and orthoclase) (Figure 10a). 

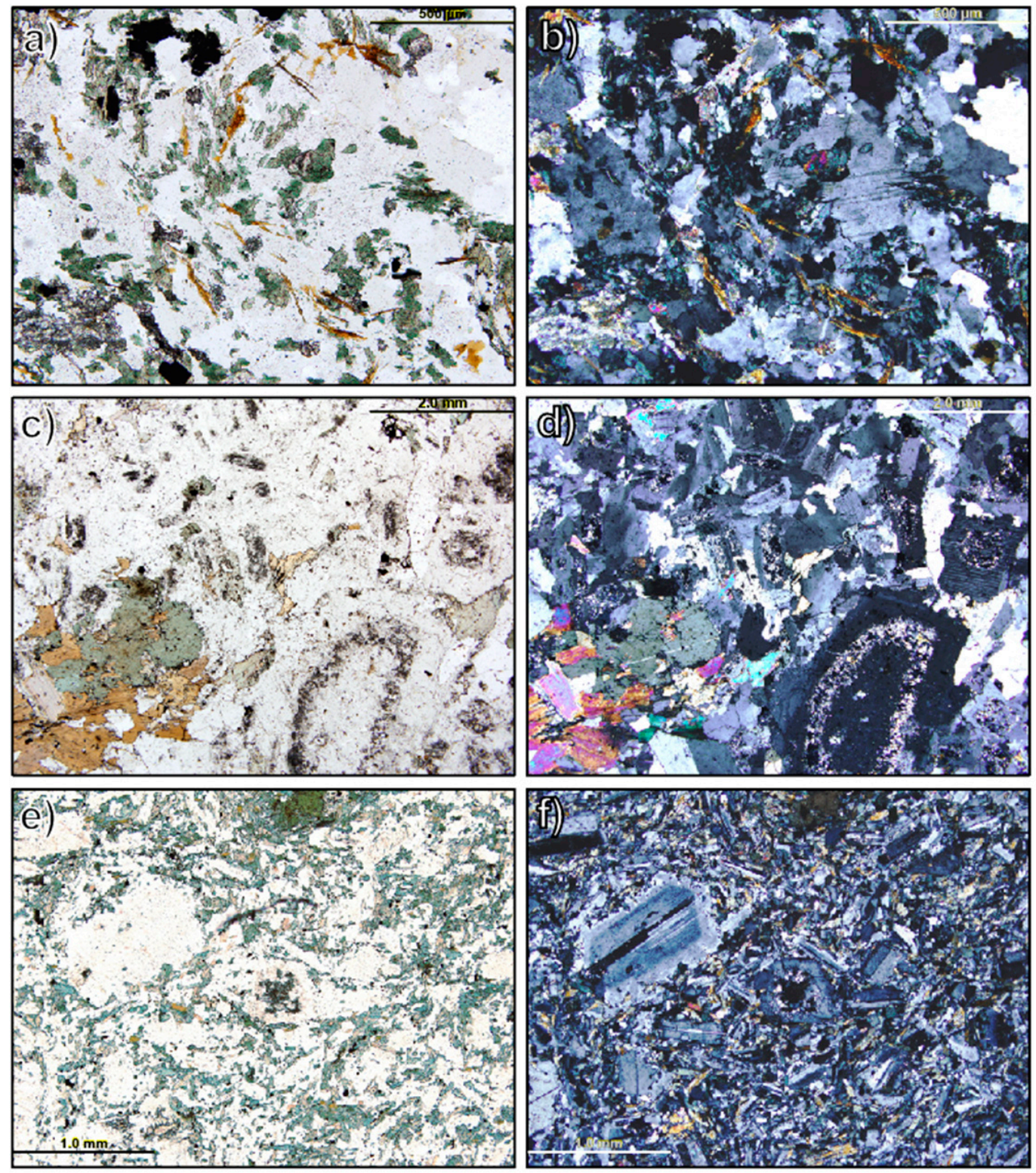

Figure 8. Cross polarized $(\mathbf{b}, \mathbf{d}, \mathbf{f})$ and plane transmitted $(\mathbf{a}, \mathbf{c}, \mathbf{e})$ light microphotographs. Sample 6E-22D-6A $(\mathbf{a}, \mathbf{b})$ is a meladiorite with coarse-grained hornblende, feldspar and quartz, and thinner biotite. Sample PLD-30-5A (c,d) is a quartz-diorite with large hornblende and biotite, euhedral and slightly sericitized feldspar, and interstitial quartz and feldspar. Sample 5A-21D-4I (e,f) is a meladiorite dyke with zoned feldspar phenocrysts. Supplementary Material S8 contains additional microphotographs.

\subsection{Chemistry of the Major Elements}

The samples from the Chibougamau pluton have a wide range of $\mathrm{SiO}_{2}$ compositions; mafic to felsic members are represented in the dataset (Table 4). Their alkali content is variable, likely a consequence of post-magmatic processes (Figure 11a). Despite this alteration, the samples have a discernible subalkaline affinity (Figure 11a) and most define a calc-alkaline trend on the AFM diagram (Figure 11c). The Fe and Mg contents of samples identified as diorite in the field are, however, variable (Figure 11c), and some samples may correspond to gabbro from the LDC (this layered complex has a tholeiitic affinity) as gabbro can be hard to distinguish from meladiorite in an outcrop. The Fe-Mg-enriched rocks may also correspond to accumulations of mafic phases or to samples in which feldspars were destabilized by alteration. 

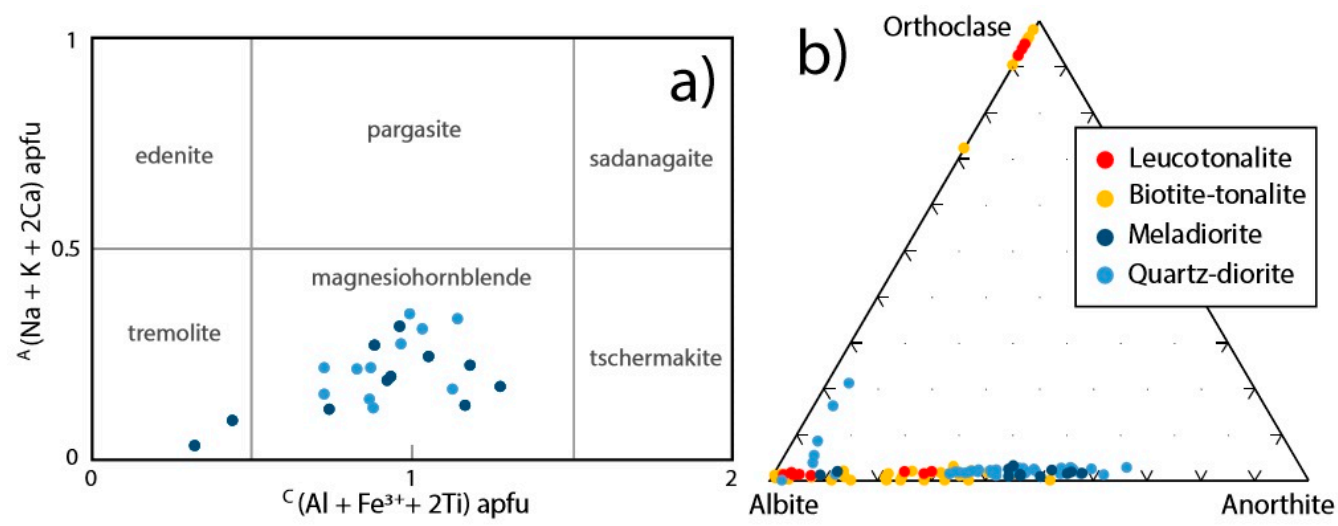

Figure 9. Composition of amphiboles (a) and feldspar (b) analyzed by microprobe in the 1980s. The diagram for calcic amphiboles (a) is from Hawthorne and collaborators [86] and contains 22 analyses performed on nine samples. The feldspar triangle (b) displays 113 analyses performed on 22 samples.

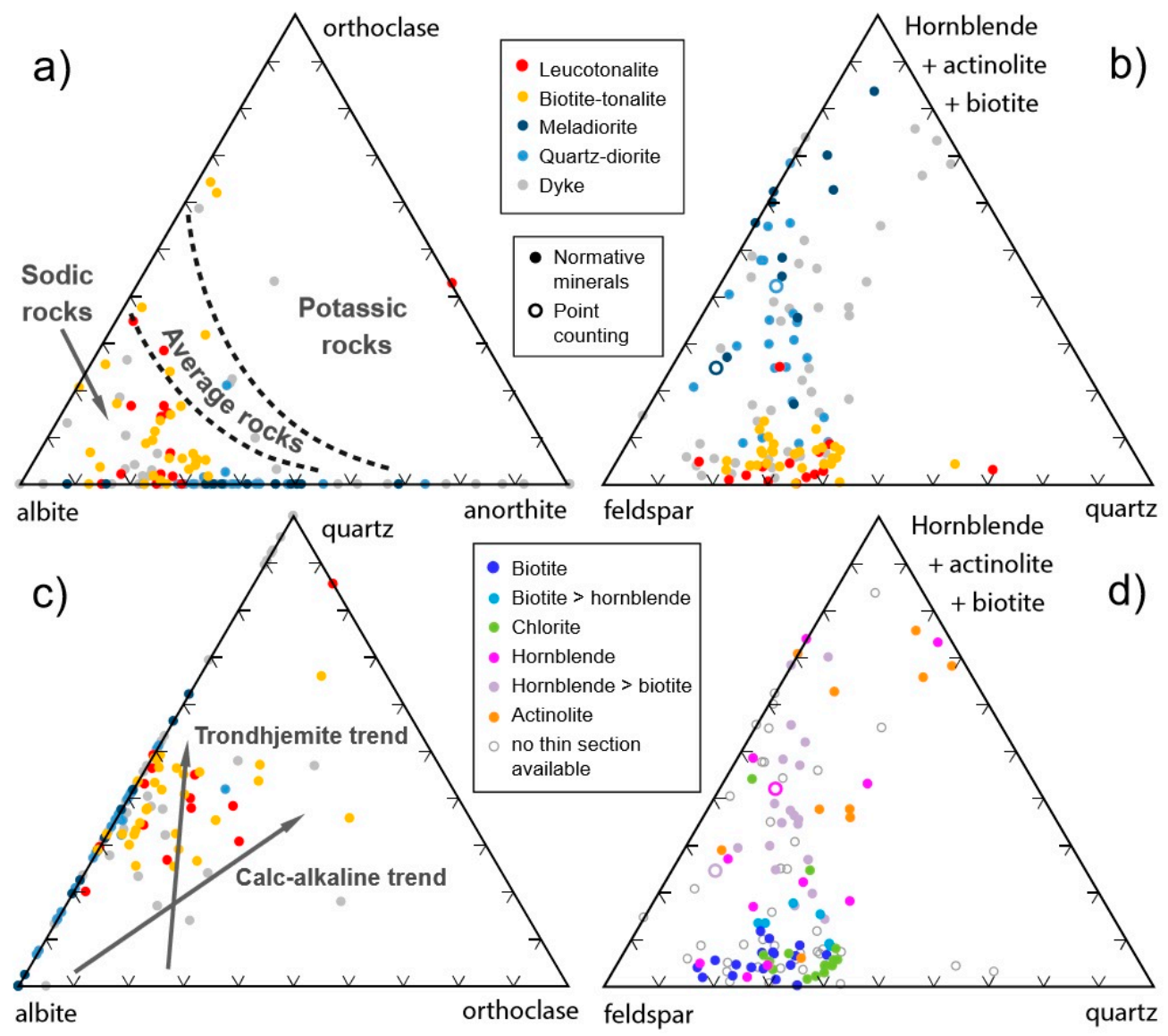

Figure 10. Normative compositions (wt \%) of the 121 samples analyzed in the 1980s and modal proportions determined with the point counting method $(n=2$; vol. \%), displayed on triangle diagrams for feldspar (a), feldspar and quartz (c), and for the main minerals observed in thin sections $(\mathbf{b}, \mathbf{d})$. The color codes correspond to the main lithology identified in the field $(\mathbf{a}, \mathbf{b}, \mathbf{c})$ and to the main ferromagnesian phase observed in thin sections (d). The area occupied by sodic and potassic rocks (a) is from Irvine and Baragar [87], and the trend lines (c) are from Barker and Arth [88].

The sampled rocks are K-poor and their alkali and Ca contents are comparable to those of experimental liquids obtained from quartz-barren basaltic sources (Figure 11d). The Na-enriched 
tonalites define a typical TTG trend. Most diorite are too Si-poor to belong to a TTG suite (Figure 11b), as will be discussed below.

The field-based distinctions made between quartz-diorite and meladiorite as well as between biotite-tonalite and leucotonalite, is not reflected by the silica, $\mathrm{Ca}$, and alkali contents of the rocks (Figure 11a,d). The four rock varieties identified in the field have, however, distinct Fe and Mg-content (Figure 11c) - they were distinguished on the basis of their ferromagnesian mineral content: meladiorite is the variety richest in hornblende, leucotonalite contains the least amount of mafic minerals (mostly biotite), and the other rock varieties are of intermediate compositions. Each variety contains plagioclase \pm alkali feldspar of variable composition.

On all diagrams, there is a clear chemical difference between the diorite phases (meladiorite and quartz-diorite varieties) and tonalites (biotite-tonalite and leucotonalite varieties) (Table 2). There is also a slight gap between the main rock types, with rocks having a $\mathrm{SiO}_{2}$ content of $\sim 63 \mathrm{wt} \%$ being least abundant (Figure 11a,c). The dykes have major element contents similar to those of the massive diorite or tonalite units (Figures 11 and 12).

Table 4. Average chemical composition of rocks recognized as meladiorite, quartz-diorite, biotite-tonalite, leucotonalite, and dykes in the field.

\begin{tabular}{|c|c|c|c|c|c|c|c|c|c|c|}
\hline \multirow{3}{*}{$\begin{array}{c}\text { Units } \\
\text { Analyses } \\
\text { Element }\end{array}$} & \multicolumn{2}{|c|}{ Meladiorite } & \multicolumn{2}{|c|}{ Quartz-Diorite } & \multicolumn{2}{|c|}{ Biotite-Tonalite } & \multicolumn{2}{|c|}{ Leucotonalite } & \multicolumn{2}{|c|}{ Dyke } \\
\hline & \multicolumn{2}{|c|}{11} & \multicolumn{2}{|c|}{22} & \multicolumn{2}{|c|}{30} & \multicolumn{2}{|c|}{14} & \multicolumn{2}{|c|}{44} \\
\hline & $\mathbf{M}^{1}$ & $\sigma^{1}$ & $\mathbf{M}$ & $\sigma$ & $\mathbf{M}$ & $\sigma$ & $\mathbf{M}$ & $\sigma$ & $\mathbf{M}$ & $\sigma$ \\
\hline $\mathrm{SiO}_{2}(\mathrm{wt} \%)$ & 49.14 & 5.82 & 57.14 & 6.28 & 69.79 & 3.37 & 71.26 & 3.44 & 58.95 & 8.38 \\
\hline $\mathrm{TiO}_{2}$ & 0.90 & 0.51 & 0.58 & 0.27 & 0.24 & 0.16 & 0.16 & 0.11 & 0.44 & 0.30 \\
\hline $\mathrm{Al}_{2} \mathrm{O}_{3}$ & 17.33 & 1.38 & 17.72 & 1.51 & 15.73 & 1.38 & 15.59 & 2.10 & 16.90 & 1.92 \\
\hline $\mathrm{CaO}$ & 9.23 & 1.60 & 7.11 & 2.01 & 2.83 & 1.26 & 3.02 & 1.05 & 5.68 & 3.35 \\
\hline $\mathrm{K}_{2} \mathrm{O}$ & 0.71 & 0.19 & 0.85 & 0.64 & 1.52 & 1.27 & 1.73 & 1.07 & 0.50 & 1.59 \\
\hline $\mathrm{Na}_{2} \mathrm{O}$ & 2.70 & 1.05 & 3.83 & 0.85 & 4.75 & 1.13 & 5.10 & 0.80 & 3.53 & 1.99 \\
\hline $\mathrm{MgO}$ & 6.71 & 2.15 & 3.73 & 2.82 & 1.02 & 0.49 & 0.47 & 1.74 & 3.25 & 3.15 \\
\hline $\mathrm{FeO}$ & 5.71 & 2.00 & 4.05 & 1.60 & 1.20 & 0.63 & 0.55 & 0.51 & 3.62 & 2.33 \\
\hline $\mathrm{Fe}_{2} \mathrm{O}_{3}$ & 2.11 & 1.26 & 1.64 & 1.35 & 1.23 & 0.64 & 1.00 & 0.46 & 1.99 & 0.81 \\
\hline $\mathrm{MnO}$ & 0.15 & 0.06 & 0.09 & 0.03 & 0.04 & 0.02 & 0.03 & 0.01 & 0.08 & 0.05 \\
\hline $\mathrm{P}_{2} \mathrm{O}_{5}$ & 0.30 & 0.33 & 0.11 & 0.15 & 0.07 & 0.06 & 0.06 & 0.05 & 0.13 & 0.16 \\
\hline$S$ & 0.08 & 0.19 & 0.04 & 0.35 & 0.04 & 0.27 & 0.02 & 0.08 & 0.07 & 0.40 \\
\hline $\mathrm{CO}_{2}$ & 0.10 & 0.41 & 0.07 & 0.32 & 0.20 & 0.83 & 0.08 & 0.54 & 0.15 & 1.78 \\
\hline $\mathrm{H}_{2} \mathrm{O}^{+}$ & 1.11 & 0.94 & 0.76 & 0.51 & 0.65 & 0.57 & 0.30 & 0.41 & 2.16 & 1.45 \\
\hline Total & 99.56 & 0.18 & 99.33 & 0.53 & 99.94 & 0.65 & 100.18 & 0.59 & 100.44 & 0.78 \\
\hline $\mathrm{Rb}(\mathrm{ppm})$ & 15.0 & 5.54 & 18.5 & 15.57 & 31.0 & 24.81 & 28.0 & 16.40 & 25.5 & 28.79 \\
\hline $\mathrm{Sr}$ & 398.0 & 121.18 & 348.0 & 191.7 & 302.0 & 241.97 & 396.0 & 291.8 & 273.0 & 212.7 \\
\hline $\mathrm{Y}$ & 14.0 & 8.58 & 13.0 & 4.33 & 10.0 & 3.86 & 8.0 & 2.95 & 13.0 & 4.79 \\
\hline $\mathrm{Nb}$ & 9.0 & 4.66 & 8.0 & 1.64 & 7.0 & 3.47 & 6.0 & 4.51 & 6.0 & 3.27 \\
\hline $\mathrm{Zr}$ & 87.0 & 39.64 & 80.5 & 37.24 & 102.0 & 59.77 & 83.0 & 36.46 & 94.5 & 37.85 \\
\hline $\mathrm{Zn}$ & 86.0 & 23.68 & 61.0 & 15.46 & 25.5 & 15.52 & 17.0 & 11.82 & 56.0 & 51.83 \\
\hline $\mathrm{Cu}$ & 38.0 & 26.00 & 18.0 & 9.90 & 3.5 & 253.71 & 2.0 & 2.15 & 23.0 & 83.25 \\
\hline $\mathrm{Ni}$ & 102.0 & 79.30 & 40.0 & 73.71 & 12.5 & 5.53 & 8.5 & 2.23 & 48.0 & 92.09 \\
\hline $\mathrm{Cr}$ & 130.0 & 97.23 & 43.0 & 160.5 & 20.0 & 7.10 & 15.0 & 6.97 & 41.0 & 168.8 \\
\hline $\mathrm{Ba}$ & 146.0 & 48.20 & 216.5 & 183.3 & 547.0 & 455.9 & 593.0 & 260.0 & 293.0 & 446.9 \\
\hline $\mathrm{V}$ & 145.0 & 64.61 & 105.5 & 84.20 & 23.0 & 11.95 & 10.0 & 9.20 & 96.5 & 62.71 \\
\hline $\mathrm{Fe}_{2} \mathrm{O}_{3} / \mathrm{FeO}$ & 0.41 & 0.14 & 0.47 & 0.28 & 1.19 & 2.15 & 1.71 & 6.41 & 0.63 & 1.92 \\
\hline $\mathrm{ASI}^{2}$ & 1.34 & 0.09 & 1.33 & 0.10 & 1.29 & 0.22 & 1.24 & 0.11 & 1.39 & 0.34 \\
\hline
\end{tabular}

On the Harker diagrams, the samples of the Chibougamau pluton define relatively coherent trends (Figure 12). These trends should not be mistaken with LLD (liquid line of descent), as will be discussed later. Alteration-induced chemical variation affects mostly the alkali and modifies very little the concentration of immobile elements, such as $\mathrm{Al}$. The rocks are enriched in $\mathrm{Al}$, and tonalite with $70 \mathrm{wt} \% \mathrm{SiO}_{2}$ contains $>15 \mathrm{wt} \% \mathrm{Al}_{2} \mathrm{O}_{3}$ (Table 5). The pluton is peraluminous, with an ASI index, defined as $\mathrm{Al} /[\mathrm{Ca}-1.67 \mathrm{P}+\mathrm{K}+\mathrm{Na}$ ] molar [89], of 1.25-1.30 and 1.34 for tonalite and diorite, respectively (Table 4). The Ti-content of diorite (median $=0.65 \mathrm{wt} \%$ ) and tonalite (median $=0.21 \mathrm{wt} \%$ ) decreases 
with increasing $\mathrm{SiO}_{2}$ content. $\mathrm{Ti}$ is mostly controlled by titanite and amphibole, while the Ti-richest rocks may contain enclaves of the titanomagnetite-enriched units of the LDC (Figure 12).

$\mathrm{K}$-content has been modified by alteration but appears higher in tonalite than in diorite. The diorite and tonalite have distinct Na-contents of 3.56 and $4.80 \mathrm{wt} \% \mathrm{Na}_{2} \mathrm{O}$ (median), respectively. The CaO-, $\mathrm{FeO}-$ and $\mathrm{MgO}-$ content, on the other hand, decreases with increasing $\mathrm{SiO}_{2}$ (Figure 12). Looking at the $\mathrm{Mg}$-content of the rocks in more detail, we observed that the diorite and tonalite align along distinct regression lines (lines A and B; Figure 11b) and may define distinct differentiation trends.

The iron content is variable, and the $\mathrm{Fe}_{2} \mathrm{O}_{3} / \mathrm{FeO}$ ratio is distinctly higher in tonalite than in diorite. Diorite and tonalite have median $\mathrm{Fe}_{2} \mathrm{O}_{3} / \mathrm{FeO}$ ratios of $0.41-0.47$ and 1.19-1.71, respectively (Figure 12, Table 4). For $\mathrm{SiO}_{2}$ ranges similar to these of diorite and tonalite, subalkaline rocks have average $\mathrm{Fe}_{2} \mathrm{O}_{3} / \mathrm{FeO}$ ratios of $0.2-0.35$ and 0.4-0.5, respectively [90]. The Chibougamau pluton thus displays an elevated $\mathrm{Fe}_{2} \mathrm{O}_{3} / \mathrm{FeO}$ ratio.

Table 5. Chemical composition of the Chibougamau pluton compared to the chemistry of tonalite-trondhjemite-granodiorite (TTGs), as reviewed by Moyen and Martin [91].

\begin{tabular}{|c|c|c|c|c|}
\hline Criteria & Low REE TTG & Med. REE TTG & High REE TTG & Not TTG \\
\hline Criterion 1. & \multicolumn{3}{|c|}{$\mathrm{SiO}_{2}>64$ wt $\% ;\left(\mathrm{Fe}_{2} \mathrm{O}_{3 \mathrm{~T}}+\mathrm{MgO}+\mathrm{MnO}+\mathrm{TiO}_{2}\right)<5$} & Other values \\
\hline $\begin{array}{l}\text { Entire dataset }(n=121 ; \\
\text { including eight } \\
\text { reanalyzed samples) }\end{array}$ & \multicolumn{3}{|c|}{$\begin{array}{c}52 \text { samples in total: } 37 \text { identified as tonalite in the field, one } \\
\text { identified as diorite, and } 14 \text { dykes }\end{array}$} & $\begin{array}{l}69 \text { samples, mostly } \\
\text { identified as diorite or } \\
\text { dykes (and seven } \\
\text { tonalite samples) }\end{array}$ \\
\hline Criterion 2. & \multicolumn{3}{|c|}{$0<\mathrm{K}_{2} \mathrm{O}<2$ wt $\%$} & Other values \\
\hline 52 felsic rocks & \multicolumn{3}{|c|}{$0.5-2 \mathrm{wt} \% \mathrm{~K}_{2} \mathrm{O}(n=29)$} & $\begin{array}{c}0.13-0.46(n=5) ; 2.14-8 \\
(n=18)\end{array}$ \\
\hline Criterion 3. & $\mathrm{Na}_{2} \mathrm{O}>5 \mathrm{wt} \%$ & \multirow{2}{*}{\multicolumn{2}{|c|}{$\begin{array}{c}4<\mathrm{Na}_{2} \mathrm{O}<6 \text { wt } \% \\
4-5(n=20) ; 4-6(n=36)\end{array}$}} & Other values \\
\hline 52 felsic rocks & $5.86 \pm 0.6(n=26)$ & & & $1.13-3.53(n=6)$ \\
\hline Criterion 4. & \multicolumn{3}{|c|}{$0.3<\mathrm{K}_{2} \mathrm{O} / \mathrm{Na}_{2} \mathrm{O}<0.6$} & Other values \\
\hline 52 felsic rocks & \multicolumn{3}{|c|}{$0.3-0.6(n=14)$} & $\begin{array}{l}0.02-0.28(n=26) ; \\
0.66-3.07(n=11)\end{array}$ \\
\hline $\begin{array}{l}\text { Criterion 5. at } 70 \text { wt \% } \\
\qquad \mathrm{SiO}_{2}\end{array}$ & $\mathrm{Al}_{2} \mathrm{O}_{3}>16 \mathrm{wt} \%$ & $\mathrm{Al}_{2} \mathrm{O}_{3}>15$ wt $\%$ & $\mathrm{Al}_{2} \mathrm{O}_{3}>14 \mathrm{wt} \%$ & Other values \\
\hline $\begin{array}{l}20 \text { samples with } 69 \text { to } 71 \\
\text { wt } \% \mathrm{SiO}_{2}\end{array}$ & $16-17.83(n=8)$ & $15-17.83(n=19)$ & $14.81(n=1)$ & none \\
\hline \multirow{2}{*}{$\begin{array}{l}\text { Criterion } 6 . \\
16 \text { tonalites with traces } \\
\text { analyzed }\end{array}$} & $\mathrm{Yb}<1 \mathrm{ppm}$ & $\mathrm{Yb}<1.5 \mathrm{ppm}$ & $\mathrm{Yb}<2 \mathrm{ppm}$ & Other values \\
\hline & $0.17-0.70(n=15)$ & all & all & none \\
\hline Criterion 7 & \multirow{2}{*}{\multicolumn{3}{|c|}{$\begin{array}{c}(\mathrm{La} / \mathrm{Yb})_{\mathrm{N}}>15 \text { and } \mathrm{La}>10 \mathrm{ppm} \\
10.4-32.8 \mathrm{ppm} \mathrm{La}(n=9) ;(\mathrm{La} / \mathrm{Yb})_{\mathrm{N}}=14.6-36.3(n=12) ; \text { both } \\
\text { criteria }(n=7)\end{array}$}} & Other values \\
\hline $\begin{array}{l}16 \text { tonalites with traces } \\
\text { analyzed }\end{array}$ & & & & $(n=9)$ \\
\hline Criterion 8 & \multirow{2}{*}{\multicolumn{3}{|c|}{$\begin{array}{l}\text { Negative } \mathrm{Ta}, \mathrm{Ti}, \mathrm{Nb} \text { anomalies, no } \mathrm{Sr} \text { or Eu anomalies } \\
\text { Most samples, except one leucotonalite without } \mathrm{Nb}-\mathrm{Ta} \\
\text { anomalies, and samples }(n=3) \text { with positive Eu anomalies }\end{array}$}} & Other values \\
\hline $\begin{array}{l}16 \text { tonalites with traces } \\
\text { analyzed }\end{array}$ & & & & $\begin{array}{l}\text { Positive Eu anomalies }(n \\
=3)\end{array}$ \\
\hline Criterion 9. & $50<\mathrm{Sr} / \mathrm{Y}<500$ & $20<\mathrm{Sr} / \mathrm{Y}<200$ & $10<\mathrm{Sr} / \mathrm{Y}<59$ & Other values \\
\hline 52 felsic rocks & $>55(n=11)$ & $20-193.33(n=38)$ & $12.73-59(n=36)$ & $1.25-9.83(n=6)$ \\
\hline
\end{tabular}

\subsection{Trace Elements}

The samples fall within the calc-alkaline to transitional fields of the $\mathrm{Th} / \mathrm{Yb}$ vs. $\mathrm{Zr} / \mathrm{Y}$ diagram (Figure 13a). These ratios of immobile elements agree with the trends observed in the TAS and AFM diagrams (Figure 11). On the $\mathrm{Zr} / \mathrm{Ti}$ vs. $\mathrm{Nb} / \mathrm{Y}$ diagram (Figure 13b), diorite and tonalite have distinct $\mathrm{Zr} / \mathrm{Ti}$ ratios that correlate with their $\mathrm{SiO}_{2}$ content. Most rocks are subalkaline based on their $\mathrm{Nb} / \mathrm{Y}$ ratio. A part of the tonalites, however, have $\mathrm{Nb} / \mathrm{Y}$ ratios $>0.65$ and fall within the alkaline field because the Winchester and Floyd diagram has not been designed for magmas depleted in elements that strongly partition into garnet (e.g., Y, Yb). The Chibougamau pluton has a calc-alkaline affinity based on its major (Figure 11a,c) and trace (Figure 13) element content. 

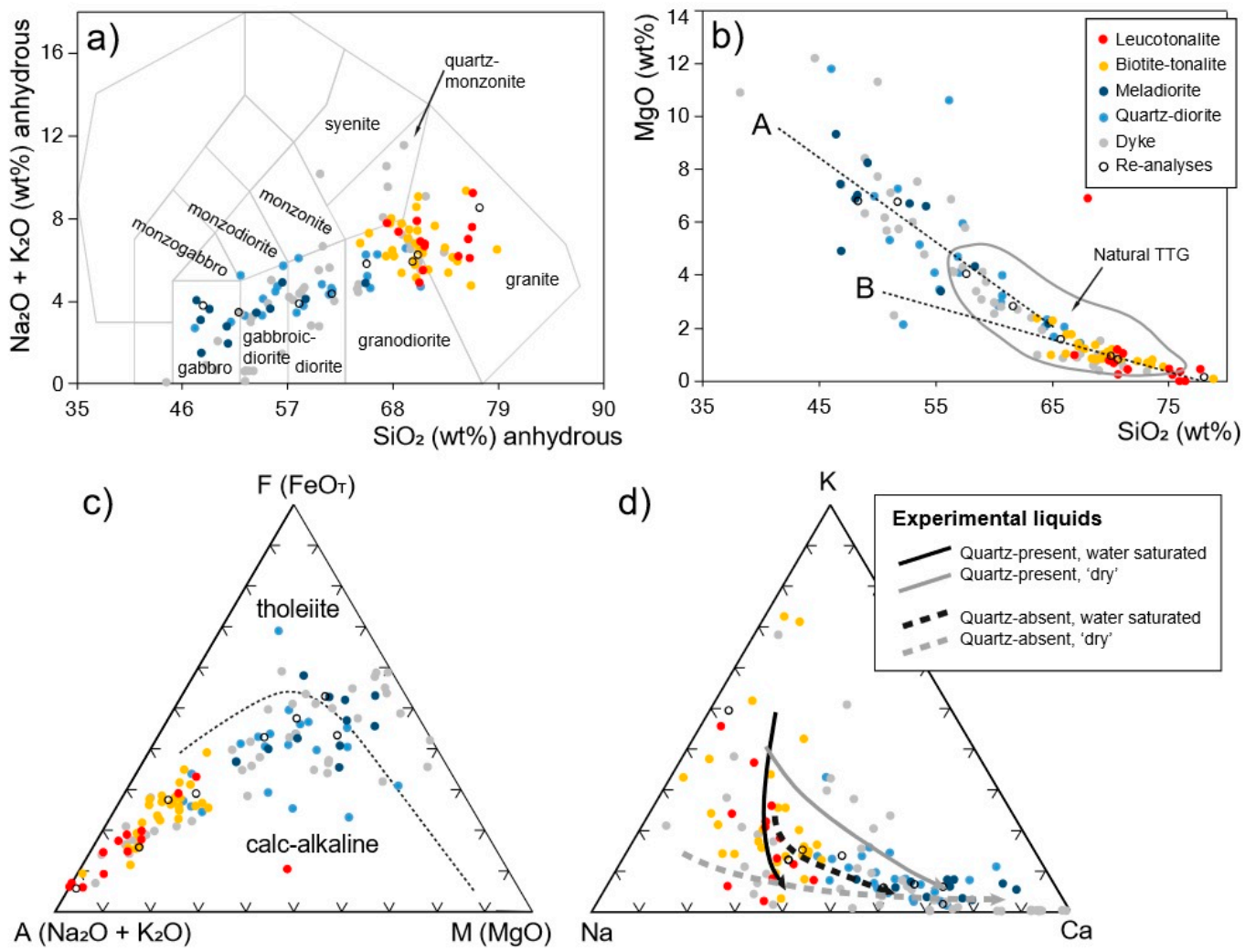

Figure 11. Samples of the Chibougamau pluton displayed using the total alkali silicate (TAS) diagram [92] (a), a $\mathrm{MgO}$ vs. $\mathrm{SiO}_{2}$ diagram (b), the alkali-iron-magnesium (AFM) diagram [93] (c), and the $\mathrm{Na}-\mathrm{K}-\mathrm{Ca}(\%)$ triangle (d). These diagrams display 121 samples analyzed in the 1980s and an additional eight reanalyzed samples. These diagrams are intended for unaltered rocks. The weakly to moderately altered rocks of the Chibougamau pluton are nonetheless displayed in these diagrams and alteration-related chemical variations are described in the text. On the $\mathrm{MgO}$ vs. $\mathrm{SiO}_{2}$ diagram, the grey field displays the average composition of high- to low-pressure TTGs ("Natural TTG") compiled by Moyen and Martin [91]. The dashed lines are regression lines going through the diorite (A) and tonalite (B) samples. The $\mathrm{Na}-\mathrm{K}-\mathrm{Ca}$ diagram displays experimental liquids compiled by Moyen and Martin [91].

The compatible element content $(\mathrm{Ni}, \mathrm{Cr}, \mathrm{V})$ decreases with increasing amounts of $\mathrm{SiO}_{2}$, and these elements are more abundant in diorite than in tonalite (Table 4). The chalcophile elements $(\mathrm{Cu}, \mathrm{Zn})$ show a similar distribution (Table 4). Other elements ( $\mathrm{Sr}, \mathrm{Y}, \mathrm{Nb}$, and $\mathrm{Zr}$ ) are uncorrelated with $\mathrm{SiO}_{2}$ and display similar concentrations in diorite and tonalite. Ba and $\mathrm{Rb}$ are most abundant in tonalite, which contains some K-feldspar and in which biotite is the dominant ferromagnesian mineral (Table 4).

In multi-element and REE diagrams, diorite and tonalite have distinct profiles (1980s and 2018 analyses; Figure 14). The dykes follow the same tendencies. On these diagrams, only one leucotonalite sample has a different profile, with positive $\mathrm{Nb}$ and Ta anomalies, negative Eu anomalies, and a relatively flat REE profile (Figure 14c,d). Examining the other profiles, we observe that tonalite is more fractionated than diorite and has $(\mathrm{La} / \mathrm{Yb})_{\mathrm{N}}$ of $23.0(\sigma=22.9, n=6)$ and $7.3(\sigma=3.1, n=15)$, respectively. Tonalite and diorite contain a comparable amount of light REE (LREE), and tonalite is depleted in heavy REE (HREE) compared to diorite (Figure 14b,d). 

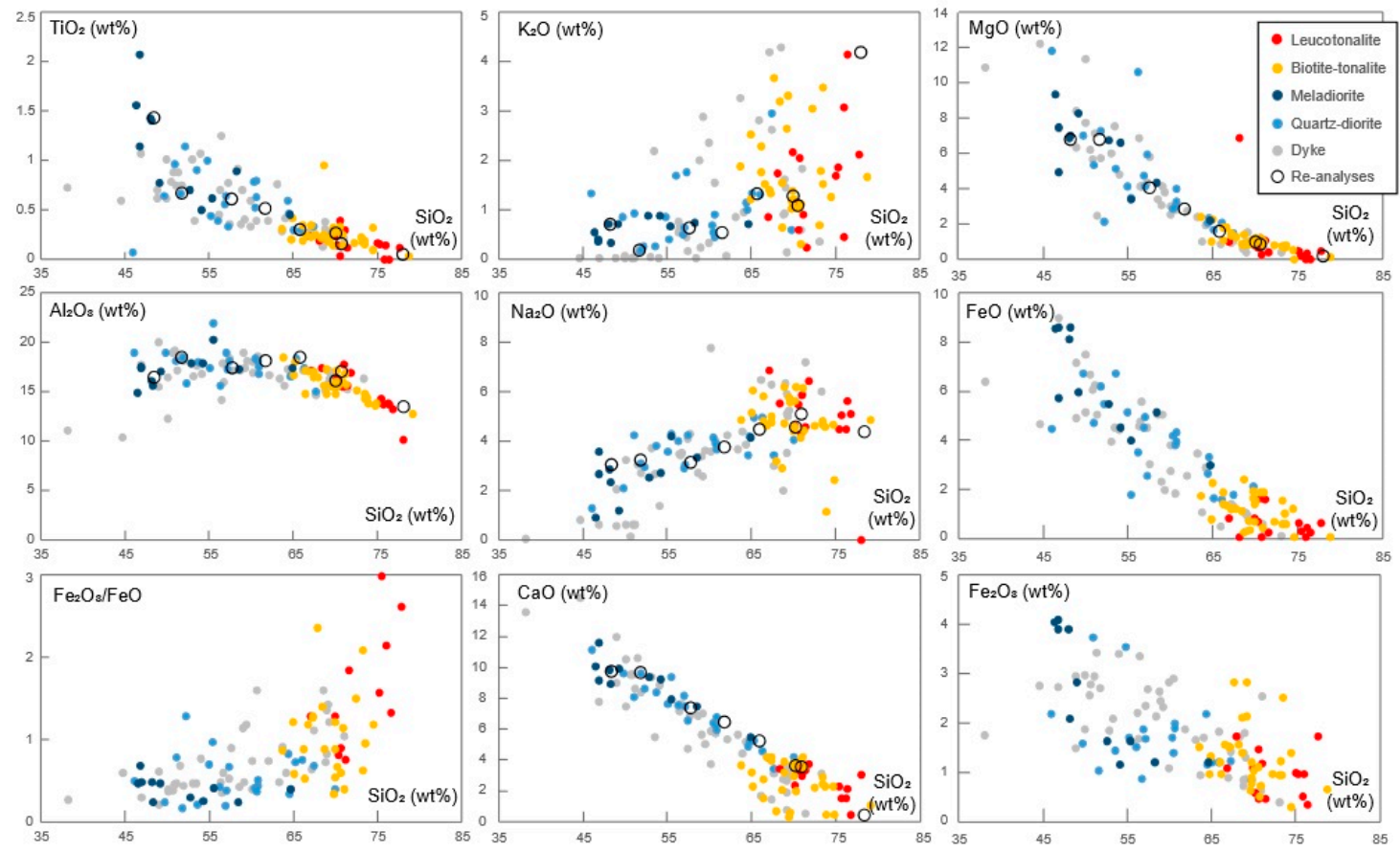

Figure 12. Harker diagrams (major or minor elements vs. $\mathrm{SiO}_{2}$ ) displaying the 121 samples analyzed in the 1980s and eight additional samples reanalyzed in 2018.
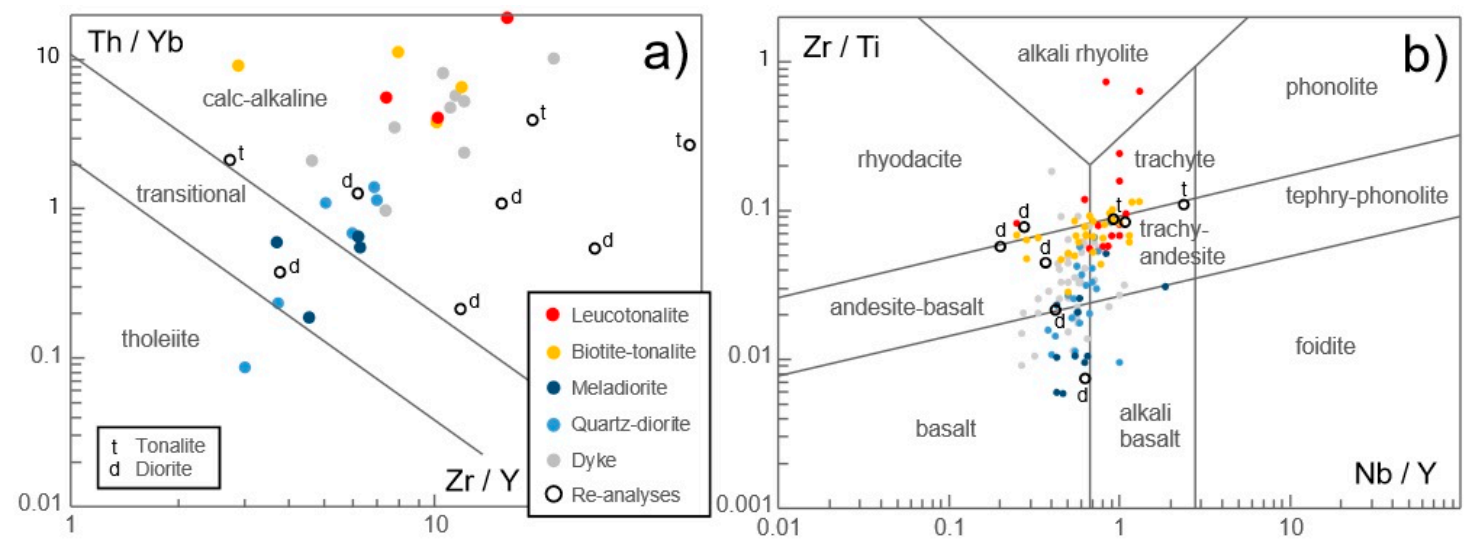

Figure 13. Samples of the Chibougamau pluton displayed on the (a) Th/Yb vs. Zr/Y diagram $(n=35)$ [94] and (b) Winchester and Floyd diagram $(n=121+8$ re-analyses) [95].

Positive Eu anomalies are observed in only three diorite and one tonalite samples and could be due to local plagioclase accumulations. The lack of Eu anomalies observed in most samples is frequent in TTGs, as the negative Eu anomalies induced by feldspar fractionation are cancelled by the positive $\mathrm{Eu}$ anomalies induced by amphibole fractionation [91,96,97]. The trace elements ( $\mathrm{Zr}, \mathrm{Hf})$, controlled by late crystallized accessory minerals (e.g., zircon), display positive and negative anomalies in tonalite and diorite, respectively (Figure 14a). Most of the diorite analyzed in 2018, however, also display positive $\mathrm{Zr}$ and $\mathrm{Hf}$ anomalies (Figure $14 \mathrm{c}$ ). $\mathrm{Ta}, \mathrm{Nb}$, and Ti negative anomalies, on the other hand, are observed in the bulk of samples, with the Ti anomaly being least developed in diorite (Figure 14a,c).

The global trace-element content of the diorite decreases with increasing $\mathrm{SiO}_{2}$ content (Figure $15 \mathrm{c}, \mathrm{d}$ ). Trace-element abundance in tonalite, on the other hand, is not correlated with $\mathrm{SiO}_{2}$ content (Figure 15a,b). 

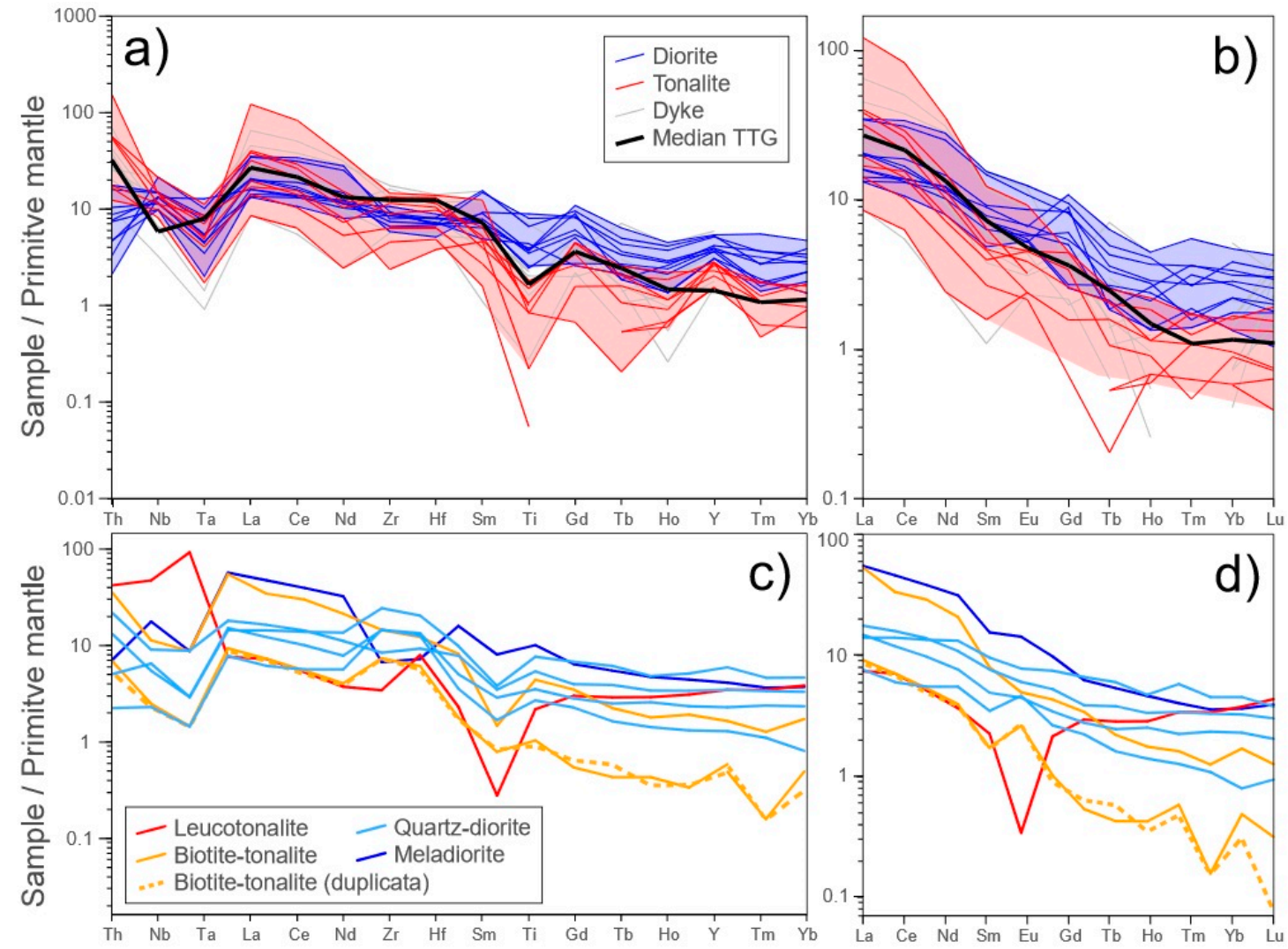

Figure 14. Multi-element diagrams (a,c) for immobile elements [98] and rare earth elements (REE) diagrams (b,d) normalized to the primitive mantle [99], displaying 27 samples (eight tonalites, 10 diorites, nine dykes; see Supplementary Material S1 for sample location) analyzed in the 1980s $(\mathbf{a}, \mathbf{b})$ and eight samples analyzed in 2018 (c,d). The Chibougamau samples are compared to the TTGs studied by Beakhouse [100] (median, $n=95$ samples).

\subsection{Comparison with TTG Suites}

Apart from late K-rich syntectonic intrusions, felsic Archean intrusions are generally included in the broad TTG category. By definition, TTGs must contain $64 \mathrm{wt} \% \mathrm{SiO}_{2}$ and must be poor in $\mathrm{Fe}$, $\mathrm{Mg}$, and Ti [91] and, based on these criteria, 52 chemical analyses were performed on TTG samples; i.e., mostly rocks identified as tonalite in the field (Table 5).

Given their alkali content, the tonalites are too K-rich to belong to a TTG suite, but K may have been added by alteration, and this criterion is thus not applicable in the Chibougamau area (Table 5). For the same reason, the $\mathrm{K}_{2} \mathrm{O} / \mathrm{Na}_{2} \mathrm{O}$ ratio of most samples is not typical of TTGs. The studied rocks are, however, sufficiently enriched in $\mathrm{Na}_{2} \mathrm{O}$ and $\mathrm{Al}_{2} \mathrm{O}_{3}$ to be TTGs, and their trace-element content also matches the TTG definition (Table 5). Most tonalites of the Chibougamau pluton are similar to "medium and high REE" TTGs (i.e., "medium to low pressure" groups) according to the criteria reviewed by Moyen and Martin [91] (see Table 5).

\section{Discussion}

Intrusive activity plays a prominent role in the mineralizing processes of the Chibougamau area. While most deposits of the Abitibi sub-province formed on the sea floor (VMS) or along fault zones (orogenic gold), the Central Camp mineralization resembles porphyry deposits. It was this particularity that motivated our study on the Chibougamau pluton, and it is likely the core element of most of the mineralizing processes of the Chibougamau area that formed ore bodies (the Lemoine mine, a VMS deposit, excluded). 


\subsection{Field Relationships}

Evidence of the shallow depth of emplacement of the pluton is ubiquitous in the field. In most outcrops, dykes and irregular-shaped injections infiltrate fractures. Where the hosting material (LDC rocks mostly) is more abundant than injections from the Chibougamau pluton, the area is described as a magmatic breccia. This prominent characteristic of the Chibougamau pluton denotes a magma emplacement style that includes: (1) fracturing of the hosting material (i.e., LDC, volcanic rocks, or previous phases of the pluton); (2) infiltration of the fractures by magma; and (3) inflation of the core of the intrusion as it is invaded by additional magma.

The abundant variations in grain size observed in the field result from the multiphase emplacement of injections and plugs of variable thickness and cooling rates. A part of the early phases may also have been unconsolidated when subsequent magma pulses were emplaced [15,16]. These features, the sharp contact between the pluton and its hosting material, as well as the absence of documented ductile deformation induced by the intrusive event all point to a stopping style of emplacement. The inflation of the pluton pushed away the roof rocks and shaped the area into the Chibougamau antiform. The anticline was further shaped by subsequent N-S compression, although the amount of deformation related to magmatic activity is hard to estimate.

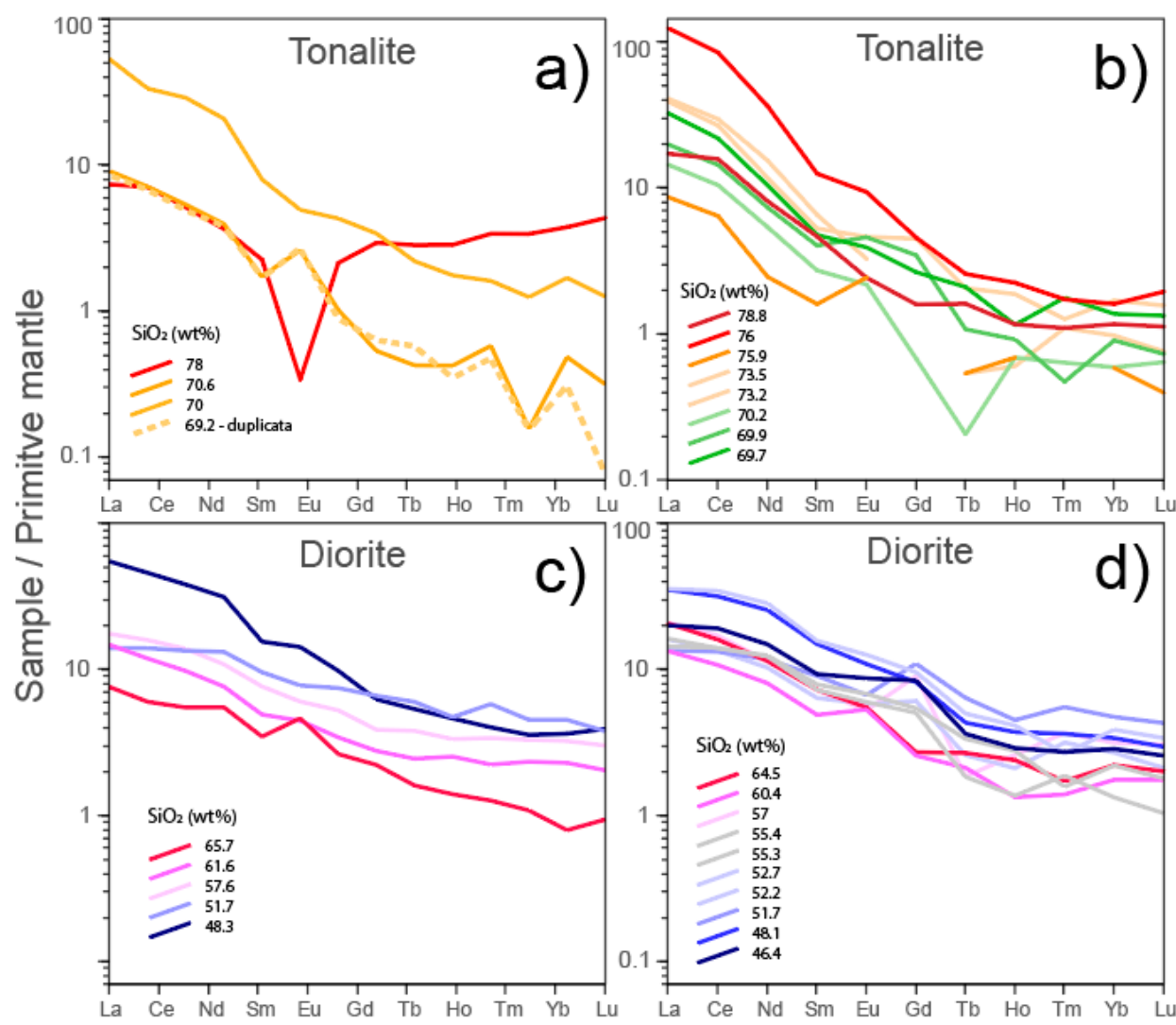

Figure 15. REE diagrams normalized to the primitive mantle [101], displaying samples of tonalite (a,b) and diorite (c,d) analyzed in the 1980s (b,d) and 2018 (a,c). The numbers correspond to the $\mathrm{SiO}_{2}(\mathrm{wt} \%$ ) content of each sample, and these values are enhanced by the color code.

In its eastern portion, the Chibougamau pluton was emplaced within the anorthosite units, named the Lower Zone [25], of the LDC. There, the pluton resembles a sill or an inflated sill (laccolith) that may have infiltrated a discontinuity within the layered LDC intrusion (Figure 2). In the central and western portions of the Chibougamau pluton, however, the magma cuts across the LDC from the Lower Zone up to the uppermost unit (i.e., the sodagranophyre) and its roof rocks (i.e., the Waconichi Formation) (Figure 2). There, the Chibougamau pluton is a thick intrusion that cuts through about $>4 \mathrm{~km}$ of 
stratigraphy (i.e., the estimated vertical thickness of the exposed portion of the LDC) [25], assuming that the LDC was an undeformed flat sill-shaped intrusion before the emplacement of the pluton.

The emplacement of the oldest phases of the Chibougamau pluton may be coeval with the eruption that formed the Blondeau Formation (ca. 1-km-thick and preserved in a synclinal) [31,101]. The pluton emplaced below the Waconichi and Bruneau Formations (ca. 2-3-km-thick) [31,102]. These thickness data are rough estimates since the formations are discontinuous, and little is known of the initial morphology of the cycle 2 volcano. It can only be speculated that the ca. 2718-2716 Ma portion of the pluton and the associated mineralized system (Central Camp) formed at ca. 3-4 km depth.

The ca. 2705-2701 Ma phase may have been emplaced at a shallower depth as it formed while the southern part of the pluton was exhumed and eroded into a sedimentary basin (Opémisca Group; Figure 2). The hydrothermal breccia observed in the southern part of the intrusion (Devlin, Queylus) may be related to this shallower intrusive event. The aerial extent of the two injection phases is unconstrained. However, in greenstone belts, the volume of magmatism tends to decrease during the syntectonic period, and the volume of the second intrusive phase may have been limited compared to that of the first phase.

Establishing the relationship between the Chibougamau pluton and magmato-hydrothermal systems should be pursued. Preliminary pyrite analysis shows an association between $\mathrm{Cu}-\mathrm{Au}$ and $\mathrm{Bi}-\mathrm{Pb}-\mathrm{Te}$. Similar element associations are reported in several porphyry systems (e.g., [103-105]) and confirm the prominence of magmatic fluids in the mineralizing systems of the Chibougamau pluton. In addition, the intrusion contained water, which is necessary for the magmatic crystallization of amphibole and biotite, but the nature of the other magmatic fluids $(\mathrm{S}, \mathrm{Cl}$, others?) remains poorly documented. The diorite is the Cu-enriched phase (Table 4) and the gold content of the magmas is un-documented. It is thus unclear whether diorite, tonalite, or both magmas were essential to the development of Central Camp mineralization, as the mineralizing processes that formed these deposits remain to be elucidated. It should, however, be noted that other Neoarchean magmato-hydrothermal systems, such as the Côté-Gold $\mathrm{Au}-(\mathrm{Cu})$ deposit (Ontario), are associated with multiphase plutons composed of diorite and low-Al tonalite [106].

\subsection{Two Distinct Magmas}

In greenstone belts, the large-volume intrusions tend to be composite and include early quartz diorite, tonalite, and granodiorite phases, as well as later tonalite, granodiorite, and granite phases [1]. The Chibougamau pluton is no exception as it is composed of early diorite followed later by tonalite. It corresponds to a tonalite-trondhjemite-diorite (TTD) suite. In cratons, low-Al TTD are subordinate compared to high-Al TTG [107], and their role in the development of $\mathrm{Cu}-\mathrm{Au}$ mineralization remains to be investigated.

The diorite and tonalite phases contain different amounts of HREE and align along different regression lines on a $\mathrm{MgO}$ vs. $\mathrm{SiO}_{2}$ diagram (Figure 11b). These phases correspond to magmas produced under different conditions and the alignment of points on various diagrams (Figures 11 and 12) should not be mistaken for LLD. The extent of fractional crystallization that occurred in each magma will be discussed in the following sections. The chemical gap between diorite and tonalite is limited, and local mixing between these phases is possible.

To test this hypothesis, the mixing test of Fourcade and Allegre [96] was performed on the samples reanalyzed in 2018 (Figure 16). This test stipulates that, if mixing occurred, the following relationship should be true for each element:

$$
C_{\mathrm{m}}-C_{\mathrm{B}}=x\left(C_{\mathrm{A}}-\mathrm{C}_{\mathrm{B}}\right),
$$

where $C$ corresponds to the concentration of each element in the mixture $(\mathrm{m})$ and in the components $\mathrm{A}$ and $\mathrm{B}$ that have mixed, and $x$ is the weight proportion of component $\mathrm{A}$.

If mixing occurred, then a straight line, having a slope corresponding to $x$, should pass through the points displayed on the $C_{\mathrm{m}}-C_{\mathrm{B}}$ vs. $C_{\mathrm{A}}-C_{\mathrm{B}}$ diagram. Displaying such a diagram for two sets of points (Figure 16) shows that the points do not align along a single line and that some points fall 
within the "forbidden zone" that is delineated by lines having slopes between 0 and 1 (i.e., grey area on Figure 16). In our study, the mixing test does not hold and therefore mixing likely played a negligible role in producing the chemical variations observed in the Chibougamau pluton.

\subsection{Magma Source and Production Conditions}

The tonalite phase is enriched in $\mathrm{Na}$ and defines a trondhjemitic trend (Figure 10c). This magma will thus be compared to the tonalite phases of the TTG suites.

The main minerals observed in TTGs are quartz, oligoclase, and biotite. Hornblende is observed in the least differentiated phases and K-feldspar is rare [91]. The tonalites within the Chibougamau pluton fit this definition as they are mostly composed of quartz, oligoclase, and biotite. The presence of andesine and hornblende indicates that some phases may be less differentiated than others. The relative abundance $(\sim 10 \%)$ of K-feldspar is likely a consequence of late hydrothermal alteration. The presence of magmatic epidote [108] is unconfirmed given the extent of greenschist facies metamorphism.

TTGs consist of three sub-groups: (1) low HREE (with garnet as a residue of partial melting); (2) medium HREE (intermediate situation); and (3) high HREE (with feldspar, \pm garnet, and no rutile in the residue) [109]. The medium HREE TTG, or medium-pressure group, are most frequent [91], and the tonalites of the Chibougamau pluton fall mostly in this category (Table 5).

As most TTGs, the tonalite of the Chibougamau pluton were likely produced by the partial melting of a hydrated basalt, as their $\mathrm{Na}, \mathrm{K}$, and Ca contents are comparable to these of experimental liquids produced from such a source (Figure 11d). As the tonalites have the chemical characteristics of medium HREE TTGs, their source rock was likely an amphibolite instead of an eclogite. The residue of partial melting likely included garnet that retained HREE (Figure 14b,d) and a titanate that retained Tb, $\mathrm{Nb}$ and $\mathrm{Ti}$ (Figure 14a,c). Given the elevated Al content of the studied rocks, partial melting occurred outside of the stability field of plagioclase. This gives a garnet-bearing amphibolite source and a depth of partial melting of $20 \mathrm{kbar}$ [110]. Most mid- to late-Archean TTGs interacted with peridotite as they raised through the mantle [107], and the tonalite of the Chibougamau pluton is probably no exception.

A higher degree of partial melting of a garnet-bearing amphibolite at a similar depth may have produced the diorite, as the extent of partial melting is the main factor that controls the compositions of these magmas [91]. A higher degree of partial melting may have diluted the effect of residual phases and higher temperatures would limit the stability field of garnet $[91,110]$, thus explaining why the diorites are less depleted in HREE than the tonalites (Figure 14). Amphibole becomes more abundant in the residue as the degree of partial melting increases [111] and residual amphibole may produce magmas with pronounced $\mathrm{Nb}$-Ta anomalies and less pronounced Ti-anomalies [112]. However, variable degrees of partial melting of a same basaltic source would not produce magmas having similar incompatible element contents (Figure 14) and may not be sufficient to enrich the diorite with compatible elements such as Ni (Table 4). The diorites may thus have a source that differs from the garnet-amphibolite postulated for the tonalite. The sources considered are:

1. An S-enriched hydrated basalt: S-bearing melts are enriched in mafic components $(\mathrm{Ca}, \mathrm{Fe}, \mathrm{Mg}, \mathrm{Ti})$ compared to melts produced experimentally from S-free material [113]. S-bearing systems also produce more melt than S-free systems [113]. The stability field of garnet, however, may not be sufficiently reduced to produce high HREE melts. Additional experiments are needed to examine the REE-content of melts produced from S-rich crustal rocks;

2. A source with a significant mantle component: The diorites have fractionated REE profiles and lack units enriched in compatible elements ( $\mathrm{Ni}<100$ ppm, Mg\# 0.4; Table 4), which rules out a peridotite-only source. The diorites do not define a calc-alkaline trend (i.e., lack of fractionation-related K-enrichment), and their source thus differs from the mantle metasomatized by fluids observed in modern subduction zones. The source of the diorite likely corresponds to mantle rocks metasomatized by TTG magmas [107]. This mantle component may be paramount in producing magmas enriched sufficiently in metals to contribute to mineralizing events. 

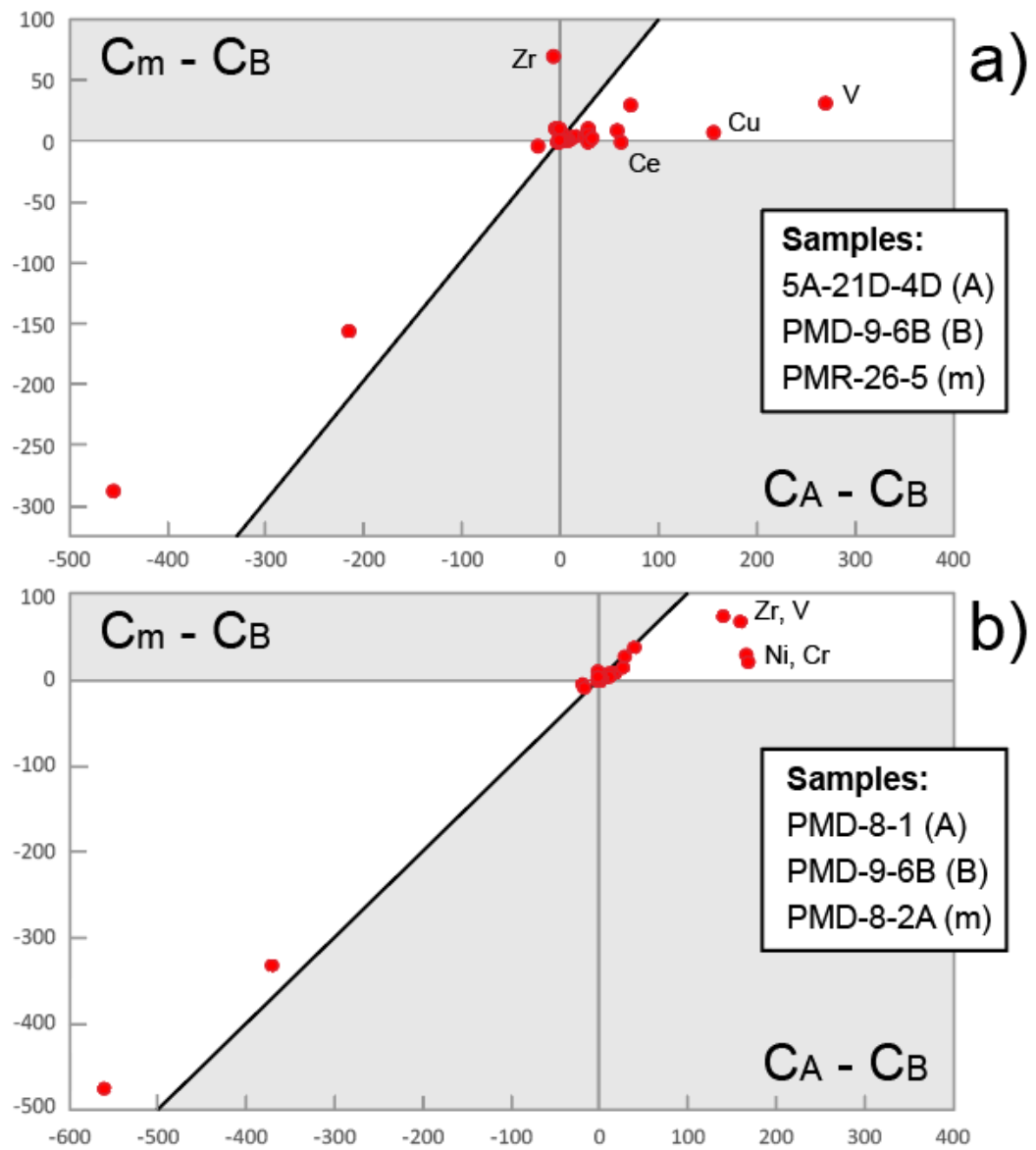

Figure 16. Mixing test between diorite and tonalite samples. The test verifies the possibility of producing the mixture $(\mathrm{m})$, which correspond to diorite enriched in $\mathrm{SiO}_{2}$, by mixing component $\mathrm{A}$ (meladiorite in (a) and $\mathrm{SiO}_{2}$-poor quartz-diorite in (b)) and component $\mathrm{B}$ (biotite-tonalite). The elements falling in the grey area do not support the mixing model.

The water content of the produced magmas is another important parameter for mineralizing systems. Diorite and tonalite contain hornblende and biotite, two minerals that crystallize from water-bearing magmas [114]. However, a large amount of volatiles would have prevented the rise of the magma to the upper levels of the crust [115]. Therefore, the water content of these magmas was likely moderate.

There is a difference between the $\mathrm{Na}, \mathrm{K}$, and $\mathrm{Ca}$ content of the experimental liquids and that of the studied tonalite (Figure 11d), the latter being more enriched in $\mathrm{K}$. This could be due to alteration, given the scatter of $\mathrm{K}_{2} \mathrm{O}$ values on a Harker diagram (Figure 12). Abnormally elevated $\mathrm{K}$-values may thus be a proxy of the alteration halo of magmato-hydrothermal systems useful in an exploration context [116]. However, this parameter may not be applicable to other contexts as, among the 10 compiled synvolcanic systems with porphyry affinities [1], the Chibougamau system is the sole system that displays K-metasomatism.

This parameter should also be used with care as elevated K-values may also characterize differentiated magmas. An example of such evolved magmas is the reanalyzed leucotonalite (sample 5A-16R-1B; see Supplementary Material S6). This sample has an elevated K-content $\left(4.21 \mathrm{wt} \% \mathrm{~K}_{2} \mathrm{O}\right)$, is enriched in $\mathrm{Si}$, and is more enriched in HREE than the other samples (Figure 15a). This rock may correspond to a differentiated melt that expulsed a large amount of LREE-bearing fluids.

To complete this discussion of the conditions surrounding magma production, we rely on the example of the late-Carboniferous Querigut complex, a multiphase intrusion located in the Pyrénées, France [96]. The Querigut complex contains felsic units (granite, monzogranite, granodiorite, tonalite) 
that were produced by crustal anatexis induced by the rise of mafic magmas (gabbro, diorite) produced by partial melting of the mantle [96]. The felsic units were produced at low pressure and, as a result, are more enriched in HREE than the tonalites of the Chibougamau pluton, that were produced in the stability field of garnet. A model that implicates a mantle-derived magma inducing anatexis during its ascent through the crust is thus not favored to explain the formation of the Chibougamau magmas.

The production of tonalite through the differentiation of diorite by the fractional crystallization of hornblende, as proposed in other contexts [97], is not favored either. Indeed, amphibole fractionation is unlikely to induce the HREE depletion observed in tonalite [115], and it would induce a positive Eu anomaly in the differentiated melt [97], a situation not observed in the studied tonalite.

The favored model includes the partial melting of hydrated basalt at $20 \mathrm{kbar}$ (to form tonalite) and of mantle rocks metasomatized by TTG melts (to form diorite). The main difference between the TTD suite of the Chibougamau pluton and more conventional TTG suites observed elsewhere in the Abitibi sub-province is a source with a significant mantle component. In the Chibougamau area, the mantle mostly produced tholeiitic magmas (i.e., Obatogamau Formation and LDC) during cycle 1 of magmatism. The onset of the volcanic cycle 2 is likely preceded by partial melting of a basaltic source that produced limited volumes of magma. This magma metasomatized the mantle while being unable to reach the crust, and partial melting of the metasomatized mantle produced diorite. Further melting of the basaltic source then produced a larger volume of TTG magma that raised through the mantle and the crust to emplace as tonalite.

As for the porphyry deposits observed in post-Archean subduction settings, metasomatized mantle is an important parameter that produces magmas capable of contributing to mineralizing systems. However, metasomatism is mostly due to crustal melts in the Archean while in more recent subduction settings, it is due to fluids from the dehydrating oceanic crust. These differences may explain the differences between the $\mathrm{Cu}-\mathrm{Au}$ deposits of Central Camp and more recent (and more conventional) porphyry mineralization. The composition of the source of the Chibougamau pluton (i.e., metal content, nature of volatiles) remains to be investigated.

\subsection{Magma Differentiation}

Most of the studied samples contain a large amount of euhedral, zoned, and >1-mm-long feldspars, as well as large amphiboles, located in thinner-grained matrices (Figures 7 and 8), and this porphyritic texture is not restricted to dykes. The coarse-grained size of a portion of the phases suggest a crystallization at depth, and the porphyritic texture indicates that the magma rose to its final emplacement depth as a crystal mush. Mushes are frequent for such magmas, as clearly stated by Tindle and Pearce, "viscous melt rarely produces clear subdivision between cumulate and liquid" [117]. Magma differentiation, after the formation of the pluton, was likely restricted to the production of aplite and pegmatite, as fractional crystallization tends to be limited in viscous magmas once they emplace as a shallow depth intrusion [96]. However, fractional crystallization may have occurred during the rise of the magma through the crust.

Fractional crystallization of tonalite and diorite is suggested by the range of $\mathrm{SiO}_{2}$ content of these phases and by the alignment of points on the Harker diagrams. For the tonalite, further evidence of differentiation is the presence of andesine and hornblende in some samples, while other samples contain biotite and oligoclase exclusively, and some samples are K-enriched (see previous sections). Fractional crystallization tends to be limited to $<25 \%$ in TTGs [91]. Additionally, the absence of correlation between $\mathrm{SiO}_{2}$ and $\mathrm{REE}$ content (Figure 15) suggests that most chemical variations within the tonalite are due to variable amounts of quartz, feldspar, and biotite. The tonalite magma pulses may have been expulsed from a deep magma chamber as mushes containing variable proportions of interstitial melt, feldspar and amphibole. The tonalite magmas then likely endured limited fractional crystallization once emplaced at shallow depth, where they exsolved fluids to produce the aplites and pegmatites observed in the field. 
The diorites display a systematic decrease in their total REE content with increasing $\mathrm{SiO}_{2}$ (Figure 15). This magma may have been differentiated by hornblende fractionation, which would lower the REE content of the residual magma [97,111]. The Eu anomaly is harder to interpret because it is influenced by the fractionation and accumulation of feldspar and amphibole, which preferentially incorporate $\mathrm{Eu}^{2+}$ and $\mathrm{Eu}^{3+}$, respectively $[118,119]$. In addition, the positive Eu anomalies observed in some of the samples might reflect local plagioclase accumulation. The evolution of the global REE content of diorite, however, points to differentiation. Evidence of fluid exsolution from the diorite (e.g., pegmatite) is currently lacking.

Oxygen fugacity $\left(\mathrm{fO}_{2}\right)$ is an important factor that controls the distribution of $\mathrm{Cu}$ and $\mathrm{Au}$ within an evolving magma $[120,121]$. The elevated $\mathrm{Fe}_{2} \mathrm{O}_{3} / \mathrm{FeO}$ of the analyzed rocks suggests an elevated $\mathrm{fO}_{2}$ (Table 4). The presence of hydrothermal magnetite in the Central Camp indicates that this ratio may, however, have been increased in the pluton by subsolidus reactions and hydrothermal alteration. Plagioclase is the most abundant phase in the bulk of the studied rocks, and fractionation of this mineral in reduced conditions should induce a negative Eu anomaly in the most differentiated diorite. The lack of Eu anomalies in most samples argues in favor of elevated $\mathrm{fO}_{2}$ conditions. Elevated $\mathrm{fO}_{2}$ values favor the retention of $\mathrm{Cu}$ and $\mathrm{Au}$ by a differentiating magma [122], making these metals available to the magmatic fluids. To reinforce this point, however, the $\mathrm{fO}_{2}$ of the Chibougamau magma should be quantified precisely using the chemistry of apatite and zircon.

Many questions remain regarding the volume of individual magma pulses, the time interval between magma pulses, and the amount of fluids that each pulse produced. These questions are important because the production of a large amount of fluids within a restricted period may be an important favorable parameter for the production of porphyry-style deposits. The emplacement of the Chibougamau pluton as a succession of crystal mushes having a potentially limited fluid production capacity may explain the limited volume of individual deposits. The repetition of this process may have formed the observed cluster of deposits. Whether these deposits are the result of a single major mineralizing event or represent a succession of small-volume events remains to be investigated by dedicated studies.

\section{Conclusions}

Magma intrusions are essential components of porphyry systems. In Archean greenstone belts, however, magma intrusions remain poorly documented and underexplored entities, as already noted in the 1980s [1]. The occurrence of porphyry-style mineralization during the Archean has now been recognized by many authors $[14,123,124]$, but much remains to be done to refine the metallogenic model of these ancient deposits. To achieve this goal, ore-body descriptions must be completed, but attention must also be paid to the associated magma intrusions.

This study describes the magmatic evolution of such an intrusion and shows that the petrogenetic model can reveal some key elements of the mineralizing processes. Much remains to be done to comprehend the Chibougamau system. However, this study shows that:

- The shallow emplacement depth and multiphase nature of the pluton are suggested. Additional timing constraints are required to evaluate, for example, whether the pluton produced a large amount of fluid at a point during its evolution, or whether magma pulses with limited volumes emplaced over a period of 2-4 Ma to build the Central Camp Cu-Au system incrementally;

- The source of the magmas was likely a mixture of garnet-bearing amphibolite and metasomatized peridotite located at $\sim 20$ kbar. Mantle rocks are not usually present in the source of large-volume Archean granitoid intrusions, and whether their presence in the source of the Chibougamau pluton was essential to the mineralizing process remains to be elucidated;

- The Chibougamau pluton is a TTD suite. Prior to alteration, it may have been more K-enriched than most of the synvolcanic intrusions of the Abitibi sub-province. These chemical features can be easily integrated to prospection models; 
- Diorites differentiated more than tonalites, but fractional crystallization remains limited in the Chibougamau pluton. Whether this factor has limited the concentration of metals and fluids in evolved magmas remains to be investigated.

Supplementary Materials: The following are available online at http:/ /www.mdpi.com/2075-163X/9/3/174/s1, S1: Table-outcrops location and description, S2: Table—legend to file S1, S3: Tables and graphics-LA-ICP-MS standards, S4: Table-LA-ICP-MS dataset, S5: Microphotographs—thin sections, S6: Table-complete dataset of whole rock analyses, S7: Table-REE analyses, S8: Table-results of normative calculations.

Author Contributions: D.R. studied the Chibougamau pluton in the 1980s, visited the outcrops, gathered the samples, and performed whole-rock analyses and petrographic observations on thin sections. D.R. also secured the funding for these analyses. L.M. compiled these data in 2018, visited some outcrops, reinterpreted the data, secured the 2018 funding, performed additional whole-rock analyses and petrographic observations, and wrote the paper.

Funding: This study was undertaken as part of the Metal Earth project (Laurentian University) investigation of the Chibougamau area, and this research was funded by Canada First Research Excellence Funds and by federal/provincial/industry partners (http:/ / merc.laurentian.ca/research/metal-earth/). This project was also funded by the NSERC (Natural Sciences and Engineering Research Council) Discovery grant of L. Mathieu (reference number RGPIN-2018-06325) and by UQAC start-up Funds. In the 1980s, D. Racicot was supported by the MRN (Ministère des Ressources Naturelles).

Acknowledgments: Many thanks to three anonymous reviewers who thoroughly reviewed this contribution. The authors are indebted to the many collaborators of the Metal Earth project, including Ross Sherlock, Harold Gibson, Bruno Lafrance, Phil C. Thurston, John Ayer, Daniel J. Kontak, and Réal Daigneault. This paper is Metal Earth contribution number MERC-ME-2019-157. The quality of the English was verified by Murray Hay (Maxafeau Editing Services) to whom warm thanks are also addressed.

Conflicts of Interest: The authors declare no conflict of interest.

\section{References}

1. Ayres, L.D.; Cerny, P. Metallogeny of granitoid rocks in the Canadian Shield. Can. Mineral. 1982, 20, 439-536.

2. Cimon, J. Possibility of an Archean porphyry copper in Quebec. Can. Min. J. 1973, 94, 1-57.

3. Guha, J.; Lange-Brard, F.; Péloquin, S.; Tremblay, A.; Racicot, D.; Bureau, S. Devlin deposit, a part of an Archean porphyry system? In Chibougamau, Stratigraphy and Mineralization; Guha, J., Chown, E., Eds.; Canadian Institute of Mining and Metallurgy: Westmount, QC, Canada, 1984; Volume 32, pp. 345-356.

4. Pilote, P.; Dion, C.; Morin, R. Géologie et évolution métallogénique de la région de Chibougamau: des gîtes de type $\mathrm{Cu}$-Au-Mo porphyriques aux gisements filoniens mésothermaux aurifères; MRN report MB-96-14; Ministère des Ressources Naturelles: Québec, QC, Canada, 1996.

5. Jébrak, M.; Doucet, P. Geology and gold-molybdenum porphyry mineralisation of the Archean Taschereau-Launay plutons, Abitibi, Quebec. Precambrian Res. 2002, 115, 329-348. [CrossRef]

6. Pilote, P. Le camp minier de Chibougamau et le parautochtone grenvillien: Métallogénie, métamorphisme et aspects structuraux. In Livret-Guide d'Excursion B1; Joined Anual Meeting, Geological Association of Canada - Mineralogical Association of Canada (GAC-MAC): Montréal, QC, Canada, 2006; p. 138.

7. Pilote, P.; Robert, F.; Kirkham, R.; Daigneault, R.; Sinclair, W.D. Minéralisation de type porphyrique et filonienne dans le Complexe du lac Doré-le secteur du lac Clark et de l'île Merrill. In Géologie et métallogénie du district minier de Chapais-Chibougamau: Nouvelle vision du potentiel de découverte; Pilote, P., Ed.; MRN report DV 98-03; Ministère des Ressources Naturelles: Québec, QC, Canada, 1998; pp. 71-90.

8. Pilote, P.; Kirkham, R.V.; Robert, F.; Sinclair, W.D.; Daigneault, R.; Magnan, M. Développement d'un District à Minéralisation de type $\mathrm{Cu}-\mathrm{Au}(\mathrm{Mo})$ Porphyrique dans la Région de Chibougamau et Implications Métallogéniques; MRN report DV 95-04; Ministère des Ressources Naturelles: Québec, QC, Canada, 1995.

9. Pilote, P.; Cimon, J.; Dion, C.; Kirkham, R.; Robert, F.; Sinclair, W.D.; Daigneault, R. Les Gisements de Type Cu-Au Porphyrique de la Région de Chibougamau; MRN report DP 93-02; Ministère des Ressources Naturelles: Québec, QC, Canada, 1993.

10. Magnan, M.; Daigneault, R.; Robert, F.; Pilote, P. Intrusion-related Au-Cu-Ag sulfide rich veins in the Archean Doré Lake Complex, Chibougamau, Québec. In Proceedings of the International Conference on Tectonics and Metallogeny of Early/Mid Proterozoic Orogenic Belts, Precambrian '95, Montreal, QC, Canada, 28 August-1 September 1995; p. 296. 
11. Pilote, P.; Cimon, J.; Dion, C.; Kirkham, R.V.; Robert, F.; Sinclair, W.D.; Daigneault, R. Les minéralisations de type porphyrique de la région de Chibougamau: Connections possibles avec les gisements filoniens de la région de lac Doré? In Proceedings of the Congrès annuel de l'Association Professionnel des Géologues et Géophysiciens du Québec (APGGQ), Val-d'Or, QC, Canada, 1-3 May 1994; p. 100.

12. Pilote, P.; Allard, G.O.; Bellevance, Y.; Blais, A.; Brisson, H.; Chown, E.; Daigneault, R.; de Corta, H.; Dion, C.; Gervais, D.; et al. Géologie et métallogénie du district minier de Chapais-Chibougamau: Nouvelle vision du potentiel de découverte; MRN report DV-98-03; Ministère des Ressources Naturelles: Québec, QC, Canada, 1998.

13. Guha, J.; Chown, E.; Archambault, G.; Barnes, S.-J.; Brisson, H.; Daigneault, R.; Dion, C.; Dubé, B.; Mueller, W.U.; Pilote, P. Metallogeny in relation to magmatic and structural evolution of an Archean greenstone belt: Chibougamau mining district. In Gold and Base-Metal Mineralization in the Abitibi Subprovince, Canada, with Emphasis on the Québec Segment; Hoe, S.E., Robert, F., Groves, D.I., Eds.; The University of Western Australia: Perth, Australia, 1990; pp. 121-166.

14. Sinclair, W.D. Porphyry deposits. In Mineral Deposits of Canada: A Synthesis of Major Deposit-Types, District Metallogeny, the Evolution of Geological Provinces, and Exploration Methods; Geological Association of Canada, Mineral Deposits Division: St. John's, NL, Canada, 2007; Volume 5, pp. 223-243.

15. Racicot, D. Géochimie et Métallogénie des Parties Occidentale et Centrale du Pluton de Chibougamau; MRN report DPV-834; Ministère des Ressources Naturelles: Québec, QC, Canada, 1981; ISBN 255001944X.

16. Racicot, D. Géochimie et Métallogénie de la Partie Orientale du Pluton de Chibougamau; MRN report DPV-758; Ministère des Ressources Naturelles: Québec, QC, Canada, 1980; ISBN 2551040272.

17. Goodwin, A.M.; Ridler, R.H. The Abitibi orogenic belt. In Symposium on Basins and Geosynclines of the Canadian Shield; Baer, A.J., Ed.; Geological Association of Canada: Wininipeg, MB, Canada, 1970; Volume 70, pp. 1-31.

18. Thurston, P.C.; Ayer, J.A.; Goutier, J.; Hamilton, M.A. Depositional gaps in Abitibi greenstone belt stratigraphy: A key to exploration for syngenetic mineralization. Econ. Geol. 2008, 103, 1097-1134. [CrossRef]

19. Leclerc, F.; Roy, P.; Pilote, P.; Bédard, J.H.; Harris, L.B.; McNicoll, V.J.; van Breemen, O.; David, J.; Goulet, N. Géologie de la Région de Chibougamau; MERN report RG 2015-03; Ministère de l'Énergie et des Ressources Naturelles: Québec, QC, Canada, 2017.

20. David, J.; Vaillancourt, D.; Bandyayera, D.; Simard, M.; Goutier, J.; Pilote, P.; Dion, C.; Barbe, P. Datations U-Pb Effectuées dans les Sousprovinces d'Ashuanipi, de La Grande, d'Opinaca et d'Abitibi en 2008-2009; MERN report, RP-2010-11; Ministère de l'Énergie et des Ressources Naturelles: Québec, QC, Canada, 2011.

21. Mortensen, J.K. U-Pb geochronology of the eastern Abitibi subprovince. Part 1: Chibougamau-Matagami-Joutel region. Can. J. Earth Sci. 1993, 30, 11-28. [CrossRef]

22. Davis, D.; Simard, M.; Hammouche, H.; Bandyayera, D.; Goutier, J.; Pilote, P.; Leclerc, F.; Dion, C. Datations U-Pb Effectuées dans les Provinces du Supérieur et de Churchill en 2011-2012; MERN report RP-2014-05; Ministère de l'Énergie et des Ressources Naturelles: Québec, QC, Canada, 2014.

23. Leclerc, F.; Bédard, J.H.; Harris, L.B.; McNicoll, V.J.; Goulet, N.; Roy, P.; Houle, P. Tholeiitic to calc-alkaline cyclic volcanism in the Roy Group, Chibougamau area, Abitibi Greenstone Belt-Revised stratigraphy and implications for VHMS exploration Geological Survey of Canada Contribution 20100254. Ministère des Ressources naturelles et de la Faune Contribution 8439-2010-2011-17. Can. J. Earth Sci. 2011, 48, 661-694.

24. Leclerc, F.; Harris, L.B.; Bédard, J.H.; van Breemen, O.; Goulet, N. Structural and Stratigraphic Controls on Magmatic, Volcanogenic, and Shear Zone-Hosted Mineralization in the Chapais-Chibougamau Mining Camp, Northeastern Abitibi, Canada (1,2). Econ. Geol. 2012, 107, 963-989. [CrossRef]

25. Allard, G.O. Doré Lake Complex and its importance to Chibougamau Geology and Metallogeny; MRN report DPV-386, Ministère des Ressources Naturelles: Québec, QC, Canada, 1976.

26. Augland, L.; David, J.; Pilote, P.; Leclerc, F.; Goutier, J.; Hammouche, H.; Lafrance, I.; Takam, T.; Deschênes, P.; Guemache, M. Datations U-Pb dans les Provinces de Churchill et du Supérieur Effectuées au GEOTOP en 2012-2013; MERN report RP 2015-01; Ministère de l'Énergie et des Ressources Naturelles: Québec, QC, Canada, 2016.

27. Frarey, M.J.; Krogh, T.E. U-Pb zircon ages of late internal plutons of the Abitibi and eastern Wawa subprovinces, Ontario and Quebec. In Current Research, Part A; Geological Survey of Canada: Ottawa, ON, Canada, 1986; Paper 86-1A; pp. 43-48.

28. SIGEOM Système d'information géominière du Québec-SIGEOM. Available online: http://sigeom.mines. gouv.qc.ca (accessed on 20 August 2008).

29. MacGregor, A.M. Some milestones in the Precambrian of Southern Rhodesia. Proc. Geol. Surv. South Africa $1951,54,27-81$. 
30. Carr, S.D.; Easton, R.M.; Jamieson, R.A.; Culshaw, N.G. Geologic transect across the Grenville orogen of Ontario and New York. Can. J. Earth Sci. 2000, 37, 193-216. [CrossRef]

31. Daigneault, R.; Allard, G.O. Le Complexe du lac Doré et son environnement géologique (région de Chibougamau-sous-province de l'Abitibi); MRN report MM-89-03; Ministère des Ressources Naturelles: Québec, QC, Canada, 1990; ISBN 2551123313.

32. Cimon, J.; Gobeil, A. The Stella Formation: its implications for the genesis and relative age of the mineralization of the Chibougamau mining camp. Can. Inst. Min. Metall. Bull. 1976, 69, 96.

33. Allard, G.O.; Caty, J.L.; Chown, E.H.; Cimon, J.; Gobeil, A.; Baker, D. Stratigraphie et métallogénie de la région de Chibougamau; Geological Association of Canada-Mineralogical Association of Canada (GAC-MAC): Montréal, QC, Canada, 1979; p. 94.

34. Racicot, D.; Chown, E.H.; Hanel, T. Plutons of the Chibougamau-Desmaraisville Belt: A Preliminary Survey. In Chibougamau, Stratigraphy and Mineralization; Guha, J., Chown, E., Eds.; Canadian Institute of Mining and Metallurgy: Westmount, QC, Canada, 1984; Volume 34, pp. 178-197.

35. Krogh, T.E. Improved accuracy of $\mathrm{U}-\mathrm{Pb}$ zircon ages by the creation of more concordant systems using an air abrasion technique. Geochim. Cosmochim. Acta 1982, 46, 637-649. [CrossRef]

36. Pilote, P.; Dion, C.; Joanisse, A.; David, J.; Machado, N.; Kirkham, R.V.; Robert, F. Géochronologie des minéralisations d'affiliation magmatique de l'Abitibi, secteurs Chibougamau et de Troilus-Frotet: implications géotectoniques. In Programme et Résumés, Séminaire d'information sur La Recherche Géologique; MRN report, DV-97-03; Ministère des Ressources Naturelles: Québec, QC, Canada, 1997; p. 47.

37. McNicoll, V.; Dubé, B.; Goutier, J.; Mercier-Langevin, P.; Dion, C.; Monecke, T.; Ross, P.-S.; Thurston, P.; Pilote, P.; Bédard, J.; et al. Nouvelles Datations U-Pb Dans le Cadre du Projet ICG-3 Abitibi/Plan Cuivre: Incidences Pour l'Interprétation Géologique et l'Exploration des Métaux Usuels; MRN report DV-2008-06; Ministère des Ressources Naturelles: Québec, QC, Canada, 2008.

38. David, J.; Davis, D.W.; Dion, C.; Goutier, J.; Legault, M.; Roy, P. Datations U-Pb Effectuées dans la Sous-province de l'Abitibi en 2005-2006; MRN report RP 2007-01; Ministère des Ressources Naturelles: Québec, QC, Canada, 2007.

39. Mueller, W.; Chown, E.H.; Sharma, K.N.M.; Tait, L.; Rocheleau, M. Paleogeographic and paleotectonic evolution of a basement-controlled Archean supracrustal sequence, Chibougamau-Caopatina, Quebec. J. Geol. 1989, 97, 399-420. [CrossRef]

40. Jolly, W.T. Relations between Archean lavas and intrusive bodies of the Abitibi greenstone belt, Ontario-Québec. In Volcanic regimes in Canada; Baragar, W.R., Coleman, L.C., Hall, J.M., Eds.; Geological Association of Canada, Mineral Deposits Division: St. John's, NL, Canada, 1980; Volume 16, pp. 311-330.

41. Ludden, J.N.; Francis, D.M.; Allard, G.O. The geochemistry and evolution of the volcanic rocks of the Chibougamau region of the Abitibi metavolcanic belt. In Chibougamau, Stratigraphy and Mineralization; Guha, J., Chown, E., Eds.; Canadian Institute of Mining and Metallurgy: Westmount, QC, Canada, 1984; Volume 34, pp. 20-34.

42. Feng, R.; Kerrich, R. Geobarometry, differential block movements, and crustal, structure of the southwestern Abitibi greenstone belt, Canada. Geology 1990, 18, 870-873. [CrossRef]

43. Dimroth, E.; Imreh, L.; Goulet, N.; Rocheleau, M. Evolution of the south-central segment of the Archean Abitibi belt, Quebec. Part II: Tectonic evolution and geomechanical model. Can. J. Earth Sci. 1983, 20, 1355-1373. [CrossRef]

44. Dimroth, E.; Imreh, L.; Goulet, N.; Rocheleau, M. Evolution of the south-central segment of the Archean Abitibi Belt, Quebec. Part III: Plutonic and metamorphic evolution and geotectonic model. Can. J. Earth Sci. 1983, 20, 1374-1388. [CrossRef]

45. Dimroth, E.; Rochelau, M.; Mueller, W.; Archer, P.; Brisson, H.; Fortin, G.; Jutras, M.; Lefebvre, C.; Piché, M.; Pilote, P. Paleogeographic and paleotectonic response to magmatic processes: A case history from the Archean sequence in the Chibougamau area, Quebec. Geol. Rundschau 1985, 74, 11-32. [CrossRef]

46. Dimroth, E.; Imreh, L.; Rocheleau, M.; Goulet, N. Evolution of the south-central part of the Archean Abitibi belt, Quebec. Part I: Stratigraphy and paleogeographic model. Can. J. Earth Sci. 1982, 19, 1729-1758. [CrossRef] 
47. Daigneault, R. Une évolution tectonique et métallogénique centrée sur le pluton de Chibougamau. In Géologie et Métallogénie du District Minier de Chapais-Chibougamau: Nouvelle Vision du Potentiel de Découverte; Pilote, P., Allard, G.O., Bellevance, Y., Blais, A., Brisson, H., Chown, E., Daigneault, R., de Corta, H., Dion, C., Gervais, D., et al., Eds.; MRN report DV-98-03; Ministère des Ressources Naturelles: Québec, QC, Canada, 1998; pp. 45-52.

48. Jolly, W.T. Regional metamorphic zonation as an aid in study of Archean terrains: Abitibi region, Ontario. Can. Mineral. 1974, 12, 499-508.

49. Faure, S. Relations Entre les Minéralisations Aurifères et les Isogrades Métamorphiques en Abitibi/Relationship between Gold Mineralisations and Metamorphic Isogrades in Abitibi. Consorem project 2013-03. Available online: http:/ / www.consorem.ca/rapports_publics.html (accessed on 10 August 2018).

50. Gower, C.F.; Clifford, P.M. The structural geometry and geological history of Archean rocks at Kenora, north-western Ontario-A proposed type area for the Kenoran Orogeny. Can. J. Earth Sci. 1981, 18, 1075-1091. [CrossRef]

51. McMillan, W.J.; Panteleyev, A. Porphyry copper deposits. In Ore Deposit Models; Roberts, R.G., Sheahan, P.A., Eds.; Reprint Series; Geoscience Canada: Burnaby, BC, Canada; Volume 3, pp. 45-58.

52. Guha, J. Hydrothermal systems and correlations of mineral deposits in the Chibougamau mining districtAn overview. In Chibougamau, Stratigraphy and Mineralization; Guha, J., Chown, E., Eds.; Canadian Institute of Mining and Metallurgy: Westmount, QC, Canada, 1984; Volume 34, pp. 517-534.

53. Pilote, P. Stratigraphy, Structure et Gîtologie de la Région du Lac Berrigan, Canton de McKenzie; MRN report ET 86-02; Ministère des Ressources Naturelles: Québec, QC, Canada, 1987.

54. Guha, J.; Dubé, B.; Pilote, P.; Chown, E.H.; Archambault, G.; Bouchard, G. Gold mineralization patterns in relation to the lithologic and tectonic evolution of the Chibougamau mining district, Quebec, Canada. Miner. Depos. 1988, 23, 293-298. [CrossRef]

55. Pilote, P.; Guha, J. Métallogénie de l'extrémité Est de la Sous-Province de l'Abitibi. In Géologie et métallogénie du district minier de Chapais-Chibougamau: Nouvelle vision du potentiel de découverte; Pilote, P., Ed.; MRN report DV 98-03; Ministère des Ressources Naturelles: Québec, QC, Canada, 1998; pp. 29-43.

56. Pilote, P.; Dion, C.; Cimon, J.; Kirkham, R.V.; Robert, F.; Sinclair, W.D.; Daigneault, R.; Magnan, M. Les Minéralisations de Types Cu-Mo-Au Porphyrique et les Gisements Cu-Au Filoniens du Lac Doré, Chibougamau: Processus Hydrothermaux Distincts ou Evolution d'un Même Evénement Minéralisateur? MRN report DV 94-09; Ministère des Ressources Naturelles: Québec, QC, Canada, 1994.

57. Tessier, A.C.; Hodgson, C.J.; Lulin, J.M. Formation of a late-tectonic, mesothermal-type gold-quartz vein deposit by remobilization of metals from a magmatic-hydrothermal copper-gold deposit at the Portage copper-gold mine, Chibougamau, Québec, Canada. In Proceedings of the International Conference on Tectonics and Metallogeny of Early/Mid Proterozoic Orogenic Belts, Precambrian '95, Montreal, QC, Canada, 28 August-1 September 1995; p. 131.

58. Brooks, C. The Rb/Sr geochronology of the Archean Chibougamau pluton, Quebec. Can. J. Earth Sci. 1980, 17, 776-783. [CrossRef]

59. Tessier, A.; Hodgson, C.J. Syn-tectonic auriferous quartz-carbonate vein-type orebodies formed by metamorphic remobilization of $\mathrm{Au}$ and $\mathrm{Cu}$ from premetamorphic sulfide lenses at the Portage Mine, Chibougamau, Québec: Implications for crustal recycling of metals and the origin of meta. In Proceedings of the Geological Association of Canada/Mineralogical Association of Canada, Annual Meeting, Abstract, Waterloo, ON, Canada, 12-15 May 1994; Volume 1, p. A111.

60. Magnan, M.; Pilote, P.; Daigneault, R. Minéralisations et altérations à la Mine Copper Rand, Chibougamau; MRN report ET-98-01; Ministère des Ressources Naturelles: Québec, QC, Canada, 1999.

61. Maillet, J. Pétrographie et géochimie des dykes du camp minier de Chibougamau. Unpublished Master's Thesis, Université du Québec à Chicoutimi, Chicoutimi, QC, Canada, 1978.

62. Guha, J.; Leroy, J.; Guha, D. Significance of fluid phases associated with shear zone Cu-Au mineralization in the Doré Lake complex, Chibougamau, Quebec. Bull. Mineral. 1979, 102, 569-576.

63. Guha, J.; Kanwar, R. Vug brines-fluid inclusions: A key to the understanding of secondary gold enrichment processes and the evolution of deep brines in the Canadian Shield. In Saline Water and Gases in Crystalline Rocks; Fritz, P., Frape, S.K., Eds.; Geological Association of Canada, Mineral Deposits Division: St. John's, NL, Canada, 1987; Volume 33, pp. 95-101. 
64. Guha, J.; Koo, J. Role of fluid state mobilization during metamorphism of the Henderson ore bodies, Chibougamau, Quebec, Canada. Can. J. Earth Sci. 1975, 12, 1516-1523. [CrossRef]

65. Thorpe, R.I.; Guha, J.; Franklin, J.M.; Loveridge, W.D. Use of a Superior province lead isotope framework in interpreting mineralization stages in the Chibougamau district. In Canadian Institute of Mining and Metallurgy Special Volume; Guha, J., Chown, E., Eds.; Canadian Institute of Mining and Metallurgy: Westmount, QC, Canada, 1984; Volume 34, pp. 496-516.

66. Thorpe, R.I.; Guha, J.; Cimon, J. Evidence from lead isotopes regarding the genesis of ore deposits in the Chibougamau region, Quebec. Can. J. Earth Sci. 1981, 18, 708-723. [CrossRef]

67. Guha, J.; Archambault, G.; Leroy, J. A correlation between the evolution of mineralizing fluids and the geomechanical development of a shear zone as illustrated by the Henderson 2 Mine, Quebec. Econ. Geol. 1983, 78, 1605-1618. [CrossRef]

68. Fortey, N.J. Hydrothermal mineralization associated with minor late Caledonian intrusions in northern Britain: preliminary comments. Inst. Min. Metall. Trans. 1980, 89, 173-176.

69. Sillitoe, R.H. Gold-rich porphyry deposits: descriptive and genetic models and their role in exploration and discovery. Rev. Econ. Geol. 2000, 13, 315-345.

70. Sillitoe, R.H. Some thoughts on gold-rich porphyry copper deposits. Miner. Depos. 1979, 14, $161-174$. [CrossRef]

71. Chivas, A.R. Geochemical evidence for magmatic fluids in porphyry copper mineralization. Contrib. to Mineral. Petrol. 1982, 78, 389-403. [CrossRef]

72. Savard, D.; Bouchard-Boivin, B.; Barnes, S.-J.; Garbe-Schönberg, D. UQAC-FeS: A new series of base metal sulfide quality control reference material for LA-ICP-MS analysis. In Proceedings of the 10th International Conference on the Analysis of Geological and Environmental Materials, Sydney, Australia, 8-13 July 2018.

73. Garbe-Schönberg, D.; Müller, S. Nano-particulate pressed powder tablets for LA-ICP-MS. J. Anal. At. Spectrom. 2014, 29, 990-1000. [CrossRef]

74. Jochum, K.P.; Willbold, M.; Raczek, I.; Stoll, B.; Herwig, K. Chemical Characterisation of the USGS Reference Glasses GSA 1G, GSC 1G, GSD 1G, GSE 1G, BCR 2G, BHVO 2G and BIR 1G Using EPMA, ID TIMS, ID ICP MS and LA ICP MS. Geostand. Geoanalytical Res. 2005, 29, 285-302. [CrossRef]

75. Wilson, S.A.; Ridley, W.I.; Koenig, A.E. Development of sulfide calibration standards for the laser ablation inductively-coupled plasma mass spectrometry technique. J. Anal. At. Spectrom. 2002, 17, 406-409. [CrossRef]

76. Paton, C.; Hellstrom, J.; Paul, B.; Woodhead, J.; Hergt, J. Iolite: Freeware for the visualisation and processing of mass spectrometric data. J. Anal. At. Spectrom. 2011, 26, 2508-2518. [CrossRef]

77. Webmineral Mineralogy Database. Available online: http://webmineral.com (accessed on 1 January 2019).

78. Gourcerol, B.; Kontak, D.J.; Thurston, P.C.; Petrus, J.A. Application of La-icp-ms Sulfide Analysis and Methodology For Deciphering Elemental Paragenesis and Associations in Addition To Multi-stage Processes in Metamorphic Gold Settings. Can. Mineral. 2018, 56, 39-64. [CrossRef]

79. Morin, R. Géologie et Compilation Géologique de la Région de Chapais; MRN report MM 91-02; Ministère des Ressources Naturelles: Québec, QC, Canada, 1994.

80. Houle, P. Compilation de Surface, Interprétation Géologique; Ressources MSV, 1 map: Montrèal, QC, Canada, 1990.

81. Whitney, D.L.; Evans, B.W. Abbreviations for names of rock-forming minerals. Am. Mineral. 2010, 95, 185-187. [CrossRef]

82. Huston, D.L.; Sie, S.H.; Suter, G.F.; Cooke, D.R.; Both, R.A. Trace elements in sulfide minerals from eastern Australian volcanic-hosted massive sulfide deposits; Part I, Proton microprobe analyses of pyrite, chalcopyrite, and sphalerite, and Part II, Selenium levels in pyrite; comparison with delta $34 \mathrm{~S}$ values and implications for the source of sulfur in volcanogenic hydrothermal systems. Econ. Geol. 1995, 90, 1167-1196.

83. Large, R.R.; Danyushevsky, L.; Hollit, C.; Maslennikov, V.; Meffre, S.; Gilbert, S.; Bull, S.; Scott, R.; Emsbo, P.; Thomas, H. Gold and trace element zonation in pyrite using a laser imaging technique: implications for the timing of gold in orogenic and Carlin-style sediment-hosted deposits. Econ. Geol. 2009, 104, 635-668. [CrossRef]

84. Taylor, R.P.; Fryer, B.J. Multiple-stage hydrothermal alteration in porphyry copper systems in northern Turkey: the temporal interplay of potassic, propylitic, and phyllic fluids. Can. J. Earth Sci. 1980, 17, 901-926. [CrossRef] 
85. Barr, S.M.; O'Beirne, A.M. Petrology of the Gillis Mountain pluton, Cape Breton Island, Nova Scotia. Can. J. Earth Sci. 1981, 18, 395-404. [CrossRef]

86. Hawthorne, F.C.; Oberti, R.; Harlow, G.E.; Maresch, W.V.; Martin, R.F.; Schumacher, J.C.; Welch, M.D. Nomenclature of the amphibole supergroup. Am. Mineral. 2012, 97, 2031-2048. [CrossRef]

87. Irvine, T.N.J.; Baragar, W. A guide to the chemical classification of the common volcanic rocks. Can. J. Earth Sci. 1971, 8, 523-548. [CrossRef]

88. Barker, F.; Arth, J.G. Generation of trondhjemitic-tonalitic liquids and Archean bimodal trondhjemite-basalt suites. Geology 1976, 4, 596-600. [CrossRef]

89. Frost, B.R. Magnetic petrology; factors that control the occurrence of magnetite in crustal rocks. In Oxide Minerals: Petrologic and Magnetic Significance; Lindsley, D.H., Ed.; Mineralogical Society of America Reviews: Chantilly, VA, USA, 1991; Volume 25, pp. 489-509.

90. Middlemost, E.A.K. Iron oxidation ratios, norms and the classification of volcanic rocks. Chem. Geol. 1989, 77, 19-26. [CrossRef]

91. Moyen, J.-F.; Martin, H. Forty years of TTG research. Lithos 2012, 148, 312-336. [CrossRef]

92. Le Bas, M.J.; Le Maitre, R.W.; Woolley, A.R. The construction of the total alkali-silica chemical classification of volcanic rocks. Mineral. Petrol. 1992, 46, 1-22. [CrossRef]

93. Rickwood, P.C. Boundary lines within petrologic diagrams which use oxides of major and minor elements. Lithos 1989, 22, 247-263. [CrossRef]

94. Ross, P.-S.; Bédard, J.H. Magmatic affinity of modern and ancient subalkaline volcanic rocks determined from trace-element discriminant diagrams. Can. J. Earth Sci. 2009, 46, 823-839. [CrossRef]

95. Pearce, J.A. A user's guide to basalt discrimination diagrams. In Trace Element Geochemistry of Volcanic Rocks: Applications for Massive Sulphide Exploration; Geological Association of Canada, S.N.C., Mineral Deposits Division: St. John's, NL, Canada, 1996; Volume 12, pp. 79-113.

96. Fourcade, S.; Allegre, C.J. Trace elements behavior in granite genesis: A case study The calc-alkaline plutonic association from the Querigut complex (Pyrénées, France). Contrib. to Mineral. Petrol. 1981, 76, 177-195. [CrossRef]

97. Brown, M.; Topley, C.G.; Power, G.M. The origin of the diorites and associated rocks of Chouet, north-western Guernsey, Channel Islands. Mineral. Mag. 1980, 43, 919-929. [CrossRef]

98. Pearce, J.A. Geochemical fingerprinting of oceanic basalts with applications to ophiolite classification and the search for Archean oceanic crust. Lithos 2008, 100, 14-48. [CrossRef]

99. Hofmann, A.W. Chemical differentiation of the Earth: the relationship between mantle, continental crust, and oceanic crust. Earth Planet. Sci. Lett. 1988, 90, 297-314. [CrossRef]

100. Beakhouse, G.P. The Abitibi Subprovince Plutonic Record: Tectonic and Metallogenic Implications; Open File Report 6268; Ontario Geological Survey: Sudbury, ON, Canada, 2011.

101. Duquette, G. Demie Nord des Cantons de McKenzie et de Roy et Quart Nord-Ouest du Canton de McCorkill; MRN report DPV 837, 4 maps; Ministère des Ressources Naturelles: Québec, QC, Canada, 1982.

102. Caty, J.-L. Canton de Richardson (comté d'Abitibi-Est); MRN report DP 606. 1 map; Ministère des Ressources Naturelles: Québec, QC, Canada, 1978.

103. Voudouris, P. A comparative mineralogical study of Te-rich magmatic-hydrothermal systems in northeastern Greece. Mineral. Petrol. 2006, 87, 241-275. [CrossRef]

104. Reich, M.; Deditius, A.; Chryssoulis, S.; Li, J.-W.; Ma, C.-Q.; Parada, M.A.; Barra, F.; Mittermayr, F. Pyrite as a record of hydrothermal fluid evolution in a porphyry copper system: A SIMS/EMPA trace element study. Geochim. Cosmochim. Acta 2013, 104, 42-62. [CrossRef]

105. Franchini, M.; McFarlane, C.; Maydagan, L.; Reich, M.; Lentz, D.R.; Meinert, L.; Bouhier, V. Trace metals in pyrite and marcasite from the Agua Rica porphyry-high sulfidation epithermal deposit, Catamarca, Argentina: Textural features and metal zoning at the porphyry to epithermal transition. Ore Geol. Rev. 2015, 66, 366-387. [CrossRef]

106. Katz, L.R.; Kontak, D.J.; Dubé, B.; McNicoll, V. The geology, petrology, and geochronology of the Archean Côté Gold large-tonnage, low-grade intrusion-related $\mathrm{Au}( \pm \mathrm{Cu})$ deposit, Swayze greenstone belt, Ontario, Canada. Can. J. Earth Sci. 2017, 54, 173-202. [CrossRef]

107. Martin, H.; Smithies, R.H.; Rapp, R.; Moyen, J.-F.; Champion, D. An overview of adakite, tonalitetrondhjemite-granodiorite (TTG), and sanukitoid: Relationships and some implications for crustal evolution. Lithos 2005, 79, 1-24. [CrossRef] 
108. Schmidt, M.W.; Poli, S. Magmatic epidote. Rev. Mineral. Geochem. 2004, 56, 399-430. [CrossRef]

109. Moyen, J.-F. The composite Archaean grey gneisses: petrological significance, and evidence for a non-unique tectonic setting for Archaean crustal growth. Lithos 2011, 123, 21-36. [CrossRef]

110. Moyen, J.; Stevens, G. Experimental constraints on TTG petrogenesis: implications for Archean geodynamics. In Archean Geodynamics and Environments; Geophysical Monograph Series 164; AGU American Geophysical Union: Washington, DC, USA, 2006; Volume 164, pp. 149-175.

111. Hanson, G.N. Rare earth elements in petrogenetic studies of igneous systems. Annu. Rev. Earth Planet. Sci. 1980, 8, 371-406. [CrossRef]

112. Drummond, M.S.; Defant, M.J. A model for trondhjemite tonalite dacite genesis and crustal growth via slab melting: Archean to modern comparisons. J. Geophys. Res. Solid Earth 1990, 95, 21503-21521. [CrossRef]

113. Prouteau, G.; Scaillet, B. Experimental constraints on sulphur behaviour in subduction zones: Implications for TTG and adakite production and the global sulphur cycle since the Archean. J. Petrol. 2013, 54, 183-213. [CrossRef]

114. Yoder, H.S.; Tilley, C.E. Origin of basalt magmas: An experimental study of natural and synthetic rock systems. J. Petrol. 1962, 3, 342-532. [CrossRef]

115. Hanson, G.N. The application of trace elements to the petrogenesis of igneous rocks of granitic composition. Earth Planet. Sci. Lett. 1978, 38, 26-43. [CrossRef]

116. Mathieu, L. Quantifying hydrothermal alteration with normative minerals and other chemical tools at the Beattie Syenite, Abitibi greenstone belt, Canada. Geochemistry Explor. Environ. Anal. 2016, 16, 233-244. [CrossRef]

117. Tindle, A.G.; Pearce, J.A. Petrogenetic modelling of in situ fractional crystallization in the zoned Loch Doon Pluton, Scotland. Contrib. to Mineral. Petrol. 1981, 78, 196-207. [CrossRef]

118. Klein, M.; Stosch, H.-G.; Seck, H.A. Partitioning of high field-strength and rare-earth elements between amphibole and quartz-dioritic to tonalitic melts: An experimental study. Chem. Geol. 1997, 138, 257-271. [CrossRef]

119. Drake, M.J.; Weill, D.F. Partition of $\mathrm{Sr}, \mathrm{Ba}, \mathrm{Ca}, \mathrm{Y}, \mathrm{Eu}^{2+}, \mathrm{Eu}^{3+}$, and other REE between plagioclase feldspar and magmatic liquid: an experimental study. Geochim. Cosmochim. Acta 1975, 39, 689-712. [CrossRef]

120. Botcharnikov, R.E.; Linnen, R.L.; Wilke, M.; Holtz, F.; Jugo, P.J.; Berndt, J. High gold concentrations in sulphide-bearing magma under oxidizing conditions. Nat. Geosci. 2011, 4, 112. [CrossRef]

121. Botcharnikov, R.E.; Holtz, F.; Mungall, J.E.; Beermann, O.; Linnen, R.L.; Garbe-Schenberg, D. Behavior of gold in a magma at sulfide-sulfate transition: Revisited. Am. Mineral. 2013, 98, 1459-1464. [CrossRef]

122. Botcharnikov, R.E.; Linnen, R.L.; Holtz, F. Solubility of Au in Cl-and S-bearing hydrous silicate melts. Geochim. Cosmochim. Acta 2010, 74, 2396-2411. [CrossRef]

123. Fraser, R.J. The Lac Troilus gold-copper deposit, northwestern Quebec; a possible Archean porphyry system. Econ. Geol. 1993, 88, 1685-1699. [CrossRef]

124. Fayol, N.; Jébrak, M. Archean sanukitoid gold porphyry deposits: A new understanding and genetic model from the Lac Bachelor gold deposit, Abitibi, Canada. Econ. Geol. 2017, 112, 1913-1936. [CrossRef]

(C) 2019 by the authors. Licensee MDPI, Basel, Switzerland. This article is an open access article distributed under the terms and conditions of the Creative Commons Attribution (CC BY) license (http:/ / creativecommons.org/licenses/by/4.0/). 